\title{
13 The Annelid Platynereis dumerilii as an Experimental Model for Evo-Devo and Regeneration Studies
}

\author{
Quentin Schenkelaars and Eve Gazave
}

\section{CONTENTS}

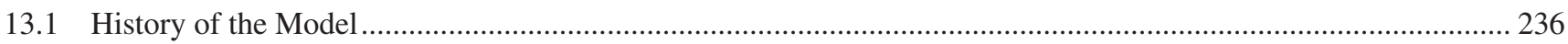

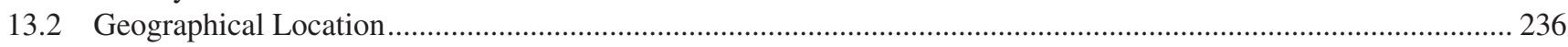

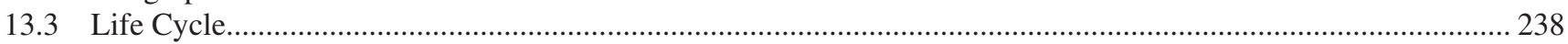

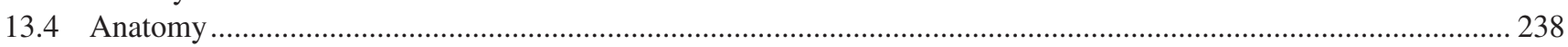

13.4.1 External Anatomy of Platynereis dumerilii Juvenile (Atoke) Worms .....................................................2238

13.4.2 Internal Anatomy of Platynereis dumerilii Juvenile (Atoke) Worms.......................................................241

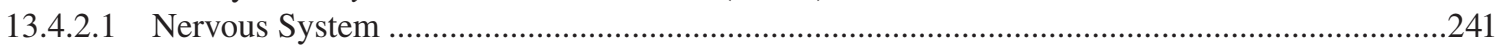

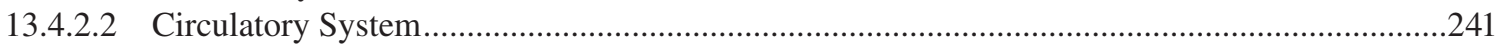

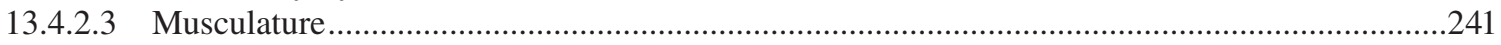

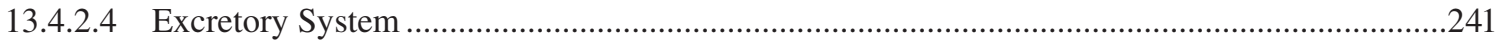

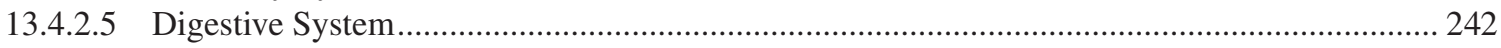

13.4.3 External and Internal Anatomy of Platynereis dumerilii Adult (Epitoke) Worms .................................... 242

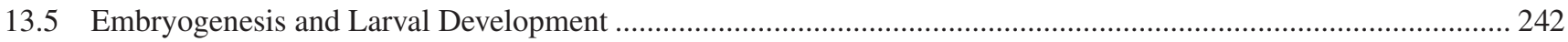

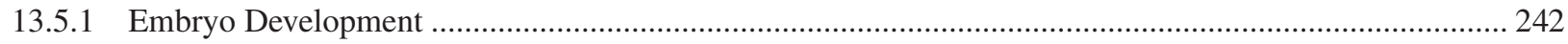

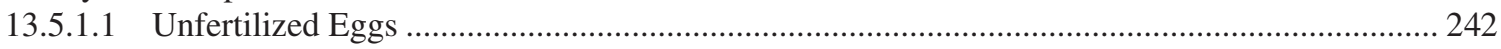

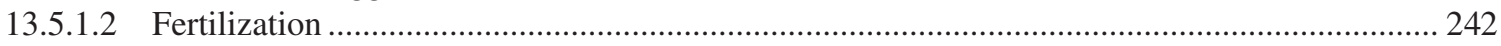

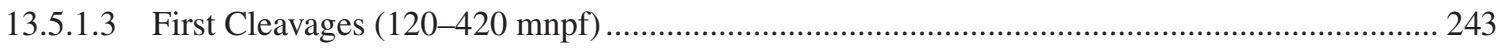

13.5.1.4 Stereoblastula/Stereogastrula/Protrochophore Larva (7-24 Hours Post-Fertilization of hpf) ... 243

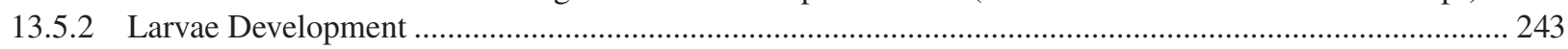

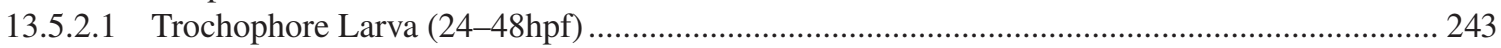

13.5.2.2 Metatrochophore Larva (48-66 hpf) .............................................................................. 245

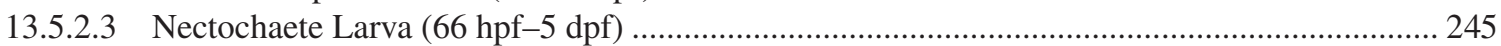

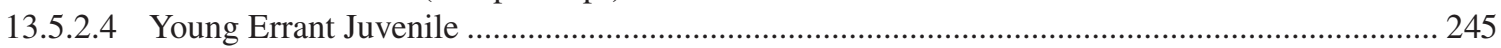

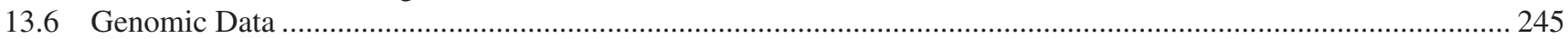

13.7 Functional Approaches: Tools for Molecular and Cellular Analyses.................................................................... 246

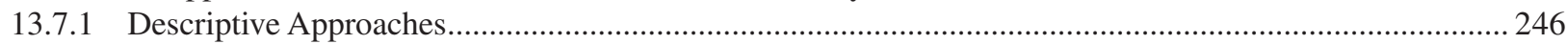

13.7.1.1 Detection of mRNA: Whole-Mount In Situ Hybridization ....................................................... 246

13.7.1.2 Detection of Proteins: Immunohistochemistry and Western Blot ........................................... 247

13.7.1.3 Tracking Cell, Cell Components and Monitoring Key Cellular Processes ................................ 247

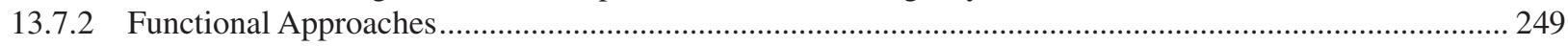

13.7.2.1 Gene Knock-Down: Translation-Blocking Morpholinos ......................................................... 249

13.7.2.2 Protein Inhibition/Activation: Pharmacological and Peptide Treatments .................................. 249

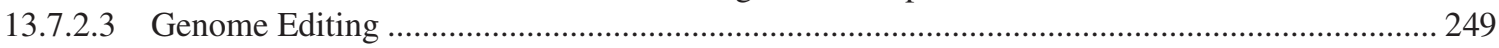

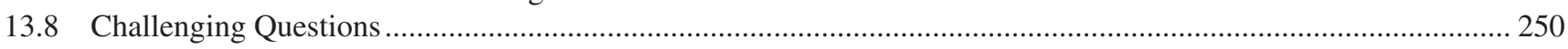

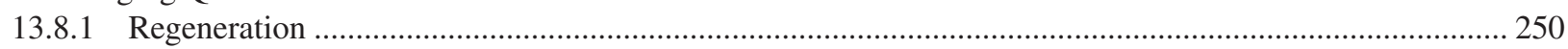

13.8.2 Epigenetic Modifications during Embryonic/Larval Development and Regeneration .................................251

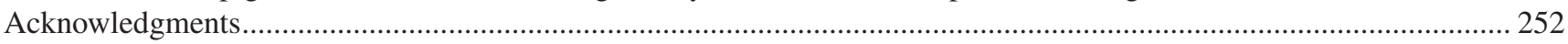

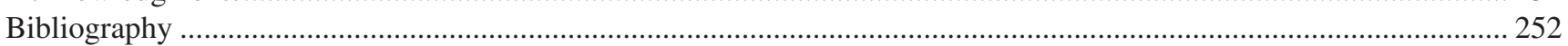




\subsection{HISTORY OF THE MODEL}

Annelids, also known as segmented worms, are a major group of non-vertebrate bilaterian animals. Annelid name comes from the Latin annellus, meaning "little ring", and refers to their segmented or metamerized body plan. Annelids represent a large number of species and an ecologically diversified animal taxon with over 18,950 described species living in various ecosystems from deep sea to rainforest canopy (Brusca and Brusca 2003). They are especially abundant in sea water but also occupy humid terrestrial and freshwater habitats. Some species are parasitic, mutualist or commensal (Rouse and Pleijel 2001; Piper 2015). Annelid species present a huge diversity of body forms coexisting with various life history strategies, being either scavengers, bioturbators, predators or filter feeders. They also harbor a multitude of (sometimes) extravagant forms of sexual and asexual reproduction (Caspers 1984; Fischer 1999; Schroeder et al. 2017). The annelid phylum, like Mollusca, Platyhelminthes, Bryozoa and more, is part of the Lophotrochozoa clade (Laumer et al. 2019), which together with Ecdyzosoa form the large group of Protostomia within Bilateria. Annelid phylogenetic relationships were, for a long time, mostly based on morphological characteristics and thus were difficult to ascertain (Weigert and Bleidorn 2016). The first classification of annelids separated them in three main groups, Polychaeta, Oligochaeta and Hirudinae (Lamarck 1818; Weigert and Bleidorn 2016). Briefly, Polychaeta, or bristle worms, referred to a large and diverse group of worms presenting numerous bristles, or chaetae, hence the name "poly-chaeta". In contrast, worms with very few or reduced chaetae were grouped together into Oligochaeta, while Hirudinae referred to worms with no chaetae and presenting a sucker. In addition, a multitude of other groups of "invertebrates" such as Sipuncula and Echiura were, at that time, considered closely related to annelids. During the $20^{\text {th }}$ century, new morphology-based classifications proposed the separation of annelids into two main groups, Polychaeta and Clitellata, the latter containing the Hirudinae (Weigert and Bleidorn 2016). Polychaeta were themselves divided into two groups, the Errantia and the Sedentaria, based on worm lifestyles. Free-moving and predatory worms were encompassed in Errantia, while sessile and tube-dwelling worms formed the Sedentaria group (de Quatrefarges 1865; Fauvel 1923, 1927). This Errantia/Sedentaria separation was dismissed with the advent of morphological cladistic analysis (Rouse and Fauchald 1997). Indeed, in 1997, Rouse and Fauchald proposed to separate Polychaeta into the clades Palpata and Scolecida based on the presence or absence of palps, respectively. Over the last 20 years, with the rise of molecular biology, the phylogenetic relationships of annelids were regularly reassessed. A recent seminal phylogenomic study highlighted the division of annelids into two main subgroups, reviving the ancient Errantia and Sedentaria nomenclature, in addition to a couple of early branching lineages such as Sipuncula (Struck et al. 2011). Errantia and Sedentaria together form the Pleistoannelida (Struck 2011).
Internal relationships among those two groups are quite well defined (Struck 2011; Weigert et al. 2014; Weigert and Bleidorn 2016). Notably, Sedentaria now also includes the Clitellata and the Echiura. The Polychaeta term is consequently no longer valid, as "polychaete worms" are present in both the Errantia and Sedentaria groups. In contrast, the phylogenetic affiliations of early branching annelid lineages (notably Sipuncula) are not yet stable (Struck et al. 2011; Weigert et al. 2014; Andrade et al. 2015; Weigert and Bleidorn 2016). Recent discovery of new annelid fossils and reassessment of their discrete morphological characters allowed for the reconciliation of annelid fossil records and new molecular phylogenetic relationships (Parry et al. 2016; Chen et al. 2020). Thanks to their huge diversity and rich phylogenetic and evolutionary histories, annelids represent a key source of potential model species to investigate a variety of biological questions, notably the evolution of developmental mechanisms (Ferrier 2012).

Among Errantia, the nereididae Platynereis dumerilii (Audouin and Milne Edwards 1833) is an important annelid model species developed by the scientific community to address key biological questions. Platynereis dumerilii, also named "Néréide de Dumeril", was discovered thanks to an oceanographic campaign around the French North coast of the English Channel (Granville, Chausey Island and Saint Malo) that occurred from 1826 to 1829. Jean Victor Audouin and Henri Milne Edwards subsequently described the type species (deposited in the La Rochelle museum, France) and named it Nereis dumerilii in their "Classification des Annélides et description de celles qui habitent les côtes de la France" book chapter containing dozens of new annelid species descriptions, especially for the Nereididae family (Audouin and Milne Edwards 1833, 1834) (Figure 13.1a). Platynereis dumerilii and Nereididae in general have been the subject of intense studies in the past century, especially regarding embryology, reproduction strategies and regeneration. Their fascinating nuptial dance behavior observed before reproduction (Just 1929; Boilly-Marer 1973; Zeeck et al. 1990), the influence of a brain hormone on their reproduction, their regeneration and growth processes (Hauenschild 1956, 1960; Hofmann 1976) and their oogenesis and spiral embryonic development (Fischer 1974; Dorresteijn et al. 1987; Dorresteijn 1990) were the main scientific questions addressed at that time. Those pioneer studies still provide important information for current challenging research questions (see Section 13.8). Carl Haeuenschild established the first Platynereis year-round laboratory culture in 1953 in Germany from a Mediterranean population (Caspers 1971). Since then, Platynereis culture procedures have been slightly refined, allowing them to be easily bred in a dozen of research laboratories all over the world (Kuehn et al. 2019).

\subsection{GEOGRAPHICAL LOCATION}

Platynereis dumerilii worms live in coastal marine waters, especially inhabiting shallow (usually between 0 and 5 meter deep), hard-bottom, algae-covered substrates. They 


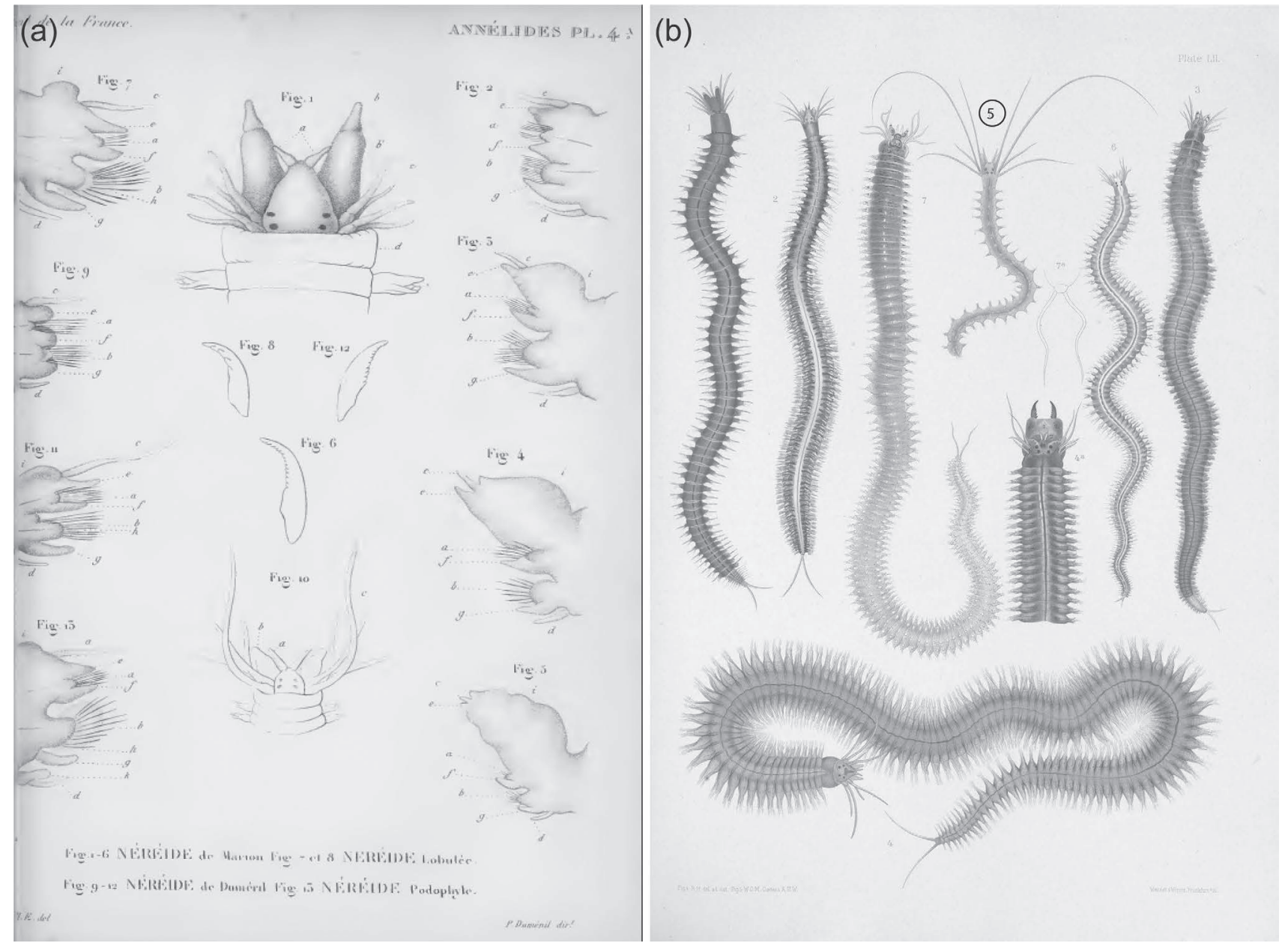

FIGURE 13.1 Original and historical drawings of Platynereis (initially named Nereis) dumerilii. (a) Drawings of the original description of Platynereis dumerilii mentioned as "Nereide de dumeril". (Plate 4A, drawings 9 to 12: $9=$ parapodia; $10=$ anterior part and head sensory structures; 11 = parapodia; 12 = denticulated jaw). (b) Drawing of annelids $(5=$ Nereis dumerilli, from a sketch drawn at Lochmaddy). ([a] From Audouin and Milne Edwards 1833, 1834; [b] from M'Intosh et al. 1910.)

can also directly live on seaweeds and marine plant leaves such as Posidonia oceanica and Zostera marina (Jacobs and Pierson 1979). As mentioned before, Platynereis dumerilii was first described from the French north coast of the English Channel. Surprisingly, Platynereis dumerilii is also found in many other locations, from temperate to tropical zones: they are often encountered throughout the Mediterranean Sea (Gambi et al. 2000) but also in the North Sea, the English Channel (Figure 13.1b), the Atlantic down to the Cape of Good Hope, the Black Sea, the Red Sea, the Persian Gulf, the Gulf of Mexico, Cuba, the Sea of Japan, the Pacific, the Kerguelen Islands and the coasts of Mozambique and South Africa (Read and Fauchald 2018; Kara et al. 2020). As a consequence of this very broad geographical distribution, Platynereis dumerilii is considered a cosmopolitan species (Fischer and Dorresteijn 2004; Read and Fauchald 2018). However, cosmopolitan species rarely exist, since they actually often pool together sibling species or a species complex with (nearly) identical morphologies (Knowlton 1993). As shown for many other marine non-vertebrates species, recent population genetic studies from the Mediterranean Sea (Italian coast) and South Africa revealed that Platynereis dumerilii, in those localities, is in fact a species complex. In Italy, $P$. dumerilii is frequently mistaken for it sibling species P. massiliensis (Moquin-Tandon 1869; Valvassori et al. 2015; Wäge et al. 2017). In South Africa, $P$. dumerilii lives in sympatry with $P$. australis (Schmarda 1861), another morphologically sibling species (Kara et al. 2020). Population genetic analysis of specimens found in South Africa initially identified as $P$. dumerilii are probably a new species, $P$. entshonae, highlighting the fact that only rigorous and broad-scale population genetic studies worldwide will help to uncover the real geographic distribution of $P$. dumerilii (Kara et al. 2020) and the diversity of the Platynereis genus that currently contains 41 valid species (Read and Fauchald 2018). 


\subsection{LIFE CYCLE}

Platynereis's life cycle exhibits several interesting features and encompasses three phases separated by metamorphosis events (Fischer and Dorresteijn 2004) (Figure 13.2). Like many other marine animals, such as corals, sea urchins and even fishes, Platynereis sexual maturation and reproduction are synchronized with the natural moon phases (Bentley et al. 1999). This fascinating biological characteristic of lunar-controlled reproductive periodicity, regulated thanks to an endogenous oscillator, is called a circalunar life cycle (Tessmar-Raible et al. 2011; Raible et al. 2017). Each worm reproduce only once, and the timing of this reproduction is tightly regulated by this clock (Zantke et al. 2013). The number of animals reaching sexual maturity is maximal shortly after the new moon and minimal during the full moon (Hauenschild 1955; Zantke et al. 2013). In nature, this reproductive period occurs between May and September in the Mediterranean Sea (Giangrande et al. 2002). When Platynereis dumerilii worms are ready to spawn, usually at night, males and females reach the surface, start an elegant nuptial dance and synchronously release eggs and sperm in a massive spawning event. This external fertilization induces the formation of thousands of small zygotes and ultimately implies the death of the reproducing males and females (Figure 13.2). By the third day, the zygote develops into small, segmented, planktonic larva named nectochaetae (see Section 13.5). Nectochaete larvae live on their own nutritive stock and move thanks to marine currents and ciliary belts. After five to seven days of planktonic life, small juvenile worms, while still able to swim, switch to a benthic/errant life mode following metamorphosis (Fischer et al. 2010). This first metamorphosis event corresponds to the disappearance of ciliated belts. Juvenile worms then continue to grow throughout their lives at a rate that is highly dependent on food availability. At some point, a second metamorphosis occurs, inducing profound morphological modifications of the head and first segment. Additionally, worms start to produce silk, important for the building of a tube in which they will live for several months. They continue to grow, to regenerate following injury and to grow posteriorly until they initiate their last metamorphosis, corresponding to the appearance of sexual traits (Fischer et al. 2010). This sexual metamorphosis is moon dependent and implies drastic morphological changes (see Section 13.4) to allow the production of thousands of gametes. During this very short reproductive period, worms become pelagic.

This eventful life cycle can be reproduced in laboratory in culture rooms maintained at $18^{\circ} \mathrm{C}$ and a daily artificial illumination regime (16 hours of light/8 hours of darkness). To induce sexual maturation, a low-light lamp is used to mimic the lunar stimulus seven days per month. A couple of days after this week of artificial full moon, juvenile (or atoke) worms start sexual maturation for a two-week period, allowing the production of sexually-mature (or epitoke) worms every day (Fischer and Dorresteijn 2004; Kuehn et al. 2019; Vervoort and Gazave in press).

\subsection{ANATOMY}

Like many other annelid species, Platynereis dumerilii worms have a complex body plan with various tissues, structures and organs that are described in the following sections for both atoke and epitoke forms.

\subsubsection{External Anatomy of Platynereis DUMERILII JUVENILE (АTOKE) WORMS}

Platynereis dumerilii juvenile worm size can be up to 90 $\mathrm{mm}$ for around 100 segments (Figure 13.3a). Their body color is highly variable, from yellowish and reddish to greenish, and this coloration mostly relies on pigmented cells, or chromatophores (Arboleda et al. 2019), that shine at the surface of the epidermis, itself secreting a cellular cuticle. While their sex is genetically determined, at the juvenile stage, male and female animals are indistinguishable. The morphology of Nereid annelids such as Platynereis is often described in zoological textbooks as representative of the typical annelid body plan, composed of three main parts: (i) an anterior region, the head with a substantial cephalization; (ii) the segmented or metamerized trunk composed of many identical units called segments, with appendages named parapodia; and (iii) a post-segmental terminal part, containing the pygidium, a differentiated structure notably containing the anus (Figure 13.3a) (Fischer and Dorresteijn 2004; Fischer et al. 2010).

Platynereis's head is composed of different structures, many of them being sensory (Chartier et al. 2018). These structures ensure crucial functions for the worm's life (Purschke 2005) (Figure 13.3b and c). To begin, Platynereis possesses two pairs of pigmented cup brown adult eyes, in a trapezoid arrangement, only visible on the dorsal part of the worm (Figure 13.3b). These pairs of adult eyes represent a distinct type of eyes in comparison to larval eyes, as revealed by their specific developmental program (Arendt et al. 2002; Guhmann et al. 2015). They also harbor a very specific cellular structure with rhabdomeric photoreceptor extensions traversing the pigmented cell layer (Arendt et al. 2002). These eyes are localized on a specific structure of the head, named the prostomium (Figure 13.3b). The prostomium also bears a pair of highly chemosensory antennae localized at the front of the head (Chartier et al. 2018) (Figure 13.3b). A pair of sensory palps are present near the antennae; based on their cellular ultrastructure (Dorsett and Hyde 1969) and a physiological experiment (Chartier et al. 2018), they have been proposed to be chemosensory as well (Figure 13.3c). The head is also composed of four pairs of long sensory and photosensitive tentacular cirri (namely anterior/posterior dorsal/ventral tentacle cirrus) (Figure 13.3c). They are involved in the worm's "shadow reflex", a defensive behavior triggered by a decrease in illumination (Ayers et al. 2018). At the posterior dorsal margin of the prostomium are nuchal organs, a pair of ciliated cavities also considered important chemosensory structures (Schmidtberg and Dorresteijn 2010; Chartier et al. 2018) 


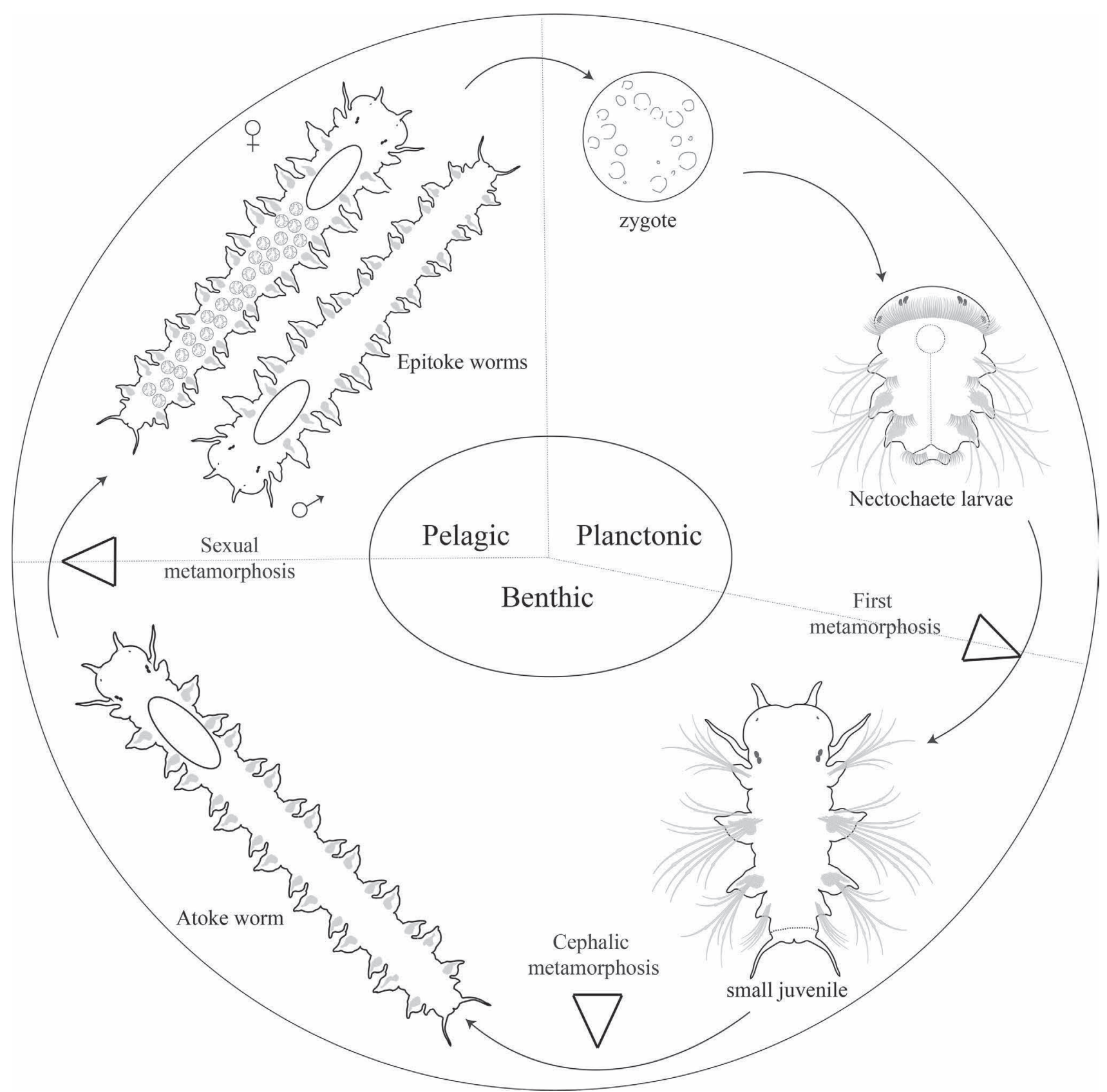

FIGURE 13.2 Platynereis dumerilii life cycle. The zygote gives rise to a small planktonic nectochaete larva within three days. After five to seven days post-fertilization (dpf), the small juvenile worm starts to feed and become benthic. Shortly thereafter, the small worm undergoes cephalic metamorphosis. The atoke worm lives inside its tube and grows continuously until sexual maturation. The sexually mature or epitoke worm then leaves its tube and swims into the water column until it performs mass spawning.

(Figure 13.3b). Finally, the aforementioned structures are located on a specific segment with no appendages, named the peristomium (Figure 13.3b). The peristomium also contains a large structure, visible only on the ventral side of the worm, which is the stomium or mouth (Figure 13.3c). Following the mouth, the pharynx contains a pair of chitinous and denticulated jaws, invaginated in the first segment of the worm, which are evaginated to catch food (Figure 13.3d). This eversible pharynx corresponds to the anterior part of the digestive tract (Verdonschot 2015).
Platynereis's trunk is composed of identical segments (Figure 13.3a). Its segmentation is thus named homonomous (Fischer and Dorresteijn 2004). Each segment is externally composed of an outer annulus and parapodia (Scholtz 2002). Parapodia are paired appendages, found in many annelids, and which have locomotion, respiratory and sensory functions (Figure 13.3e). They notably allow the worm to crawl and swim (Grimmel et al. 2016). Parapodia are biramous and thus composed of two parts, the notopodium in the dorsal side of the animal and the neuropodium in its ventral side 

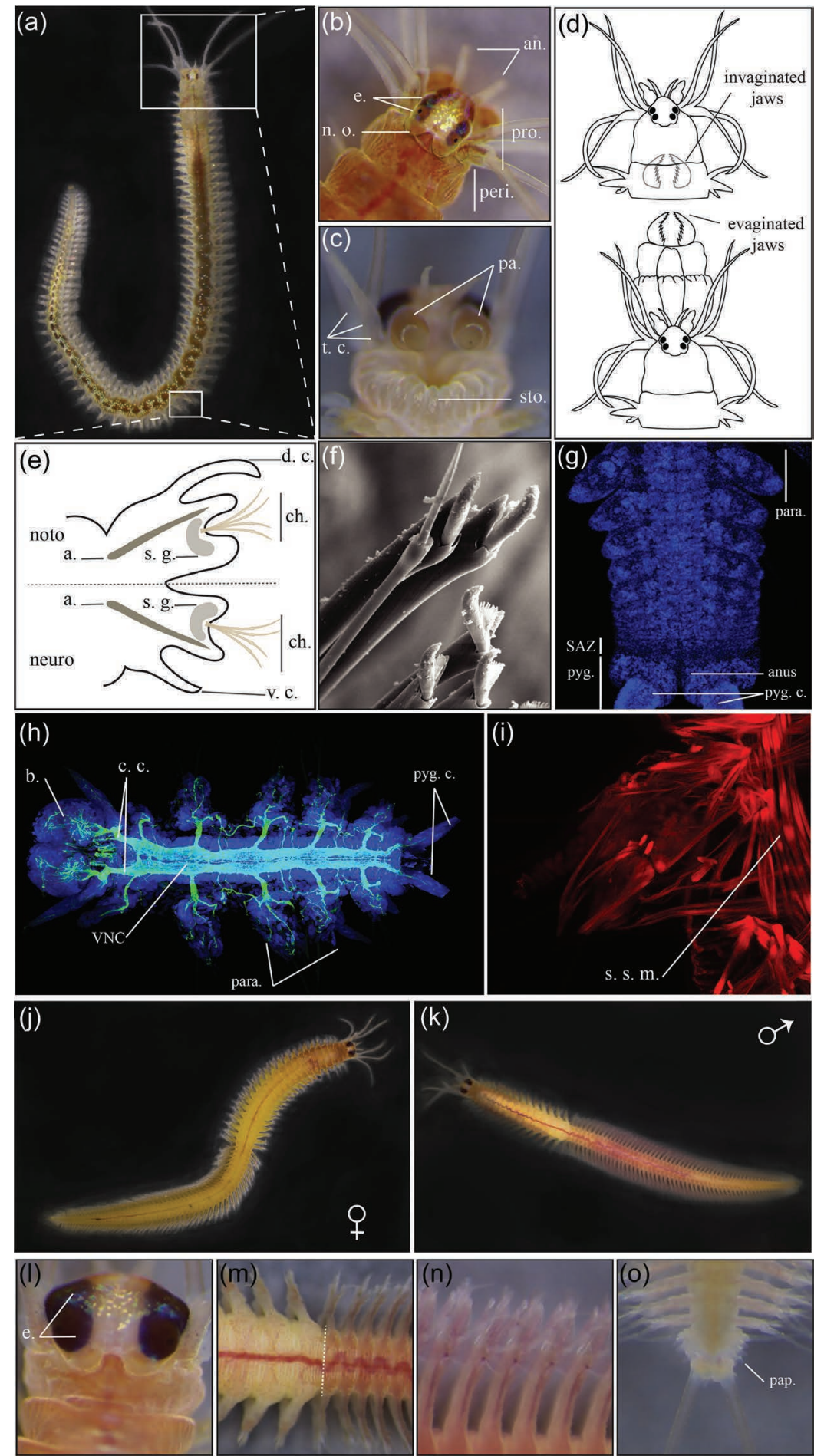

FIGURE 13.3 Anatomical features of Platynereis dumerilii atoke and epitoke worms. (a) Juvenile of Platynereis dumerilii, head (see b to d) and parapodia (see e and f) are framed. (b) Dorsal close view of the head, bearing sensory structures. (c) Ventral close view of the head, bearing the mouth or stomodeum. (d) Process of jaw evagination to catch prey. (e) Schematic representation of parapodia; the dorsal part is facing up. (f) Scanning electron microscopy (SEM) of chaetae, photo courtesy of N. Dray, PhD (CNRS). (g) Posterior part of the worm, showing the parapodia, segment addition zone, and pygidium. Hoechst nuclear staining in blue. (h) Nervous system of small juvenile worm. Ventral view; anterior is to the left. Nerves are labeled by acetylated-Tubulin antibody in green, and hoechst nuclear staining is in blue. (i) Musculature of small juvenile worm parapodia. Muscles are labeled with Phalloidin. (j) Platynereis mature female. (k) Platynereis mature male. (l) Enlarged Platynereis eyes during sexual maturation. (m) Boundary between anterior (left) and posterior (right) segments of mature worms. (n) Important blood network within the posterior parapodia of mature male. (o) Male pygidium presenting extra papillae. Abv.: a. = acicula, an. = antennae, b. = brain, c. c. = circumpharyngeal connectives, ch. = chaetae, d. $\mathrm{c} .=$ dorsal cirri, e. $=$ eye, neuro = neuropodium; n. o. = nuchal organ, noto. $=$ notopodium, pa. $=$ palps, pap. $=$ papillae, para. $=$ parapodia, peri. $=$ peristomium, pro. $=$ prostomium, pyg. = pygidium, pyg. c. $=$ pygidial cirri, $\mathrm{SAZ}=$ segment addition zone, $\mathrm{s} . \mathrm{g} .=\mathrm{spinning}$ gland, $\mathrm{s} . \mathrm{s} . \mathrm{m}$. $=$ somatic striated muscle, sto. $=$ stomium, t. c. $=$ tentacular cirri, v. c. $=$ ventral cirri, VNC $=$ ventral nerve chord. 
(Figure 13.3e). Each rami is composed of cirri (dorsal and ventral cirrus), a lobe and a beam of extracellular chitineous structures named chaetae or bristles (Verdonschot 2015) (Figure 13.3f). The latter are surrounded by specific glands that secrete material for tube or cocoon synthesis and are named spinning glands (Fischer et al. 2010). These external chaetae are constantly produced by internal structures named chaetal sacs (Gazave et al. 2017). Chaetae have a terminal articulated portion at their tips (Figure 13.3f). In addition, a robust, skeletal, internal, peculiar chaeta, named the acicula, stabilizes each lobe (Figure 13.3e). Interestingly, in annelid systematics, the shape of the parapodia and the type of chaetae are informative characteristics to determine species (Zakrzewski 2011).

The terminal part of the worm is named the pygidium (Starunov et al. 2015) (Figure 13.3g). The pygidium contains the anus and presents two sensory anal or pygidial cirri in its ventral part (Ayers et al. 2018).

\subsubsection{Internal Anatomy of Platynereis DUMERILII JUVENILE (ATOKE) WORMS}

As for its external anatomy, Platynereis's internal body plan is segmented and presents a repetition of internal structures within each segment. Indeed, each body unit contains a body cavity or coelom (separated from the next one by an incomplete intersegmental piece of tissue called septa), each containing a part of the (i) nervous system, (ii) circulatory system, (iii) musculature and (iv) excretory system (Verdonschot 2015). The non-metamerized digestive tract (v) runs along the antero-posterior axis of the worm.

\subsubsection{Nervous System}

Platynereis worms possess a central nervous system (CNS) and a peripheral nervous system (PNS). One main element of the CNS is the highly developed brain that resides in a dorsal position within the head (Starunov et al. 2017) (Figure 13.3h). Another important element of the CNS is a paired serial chain of spherical ganglia in a ventral position (named the ventral nerve chord or VNC) that runs all along the length of the worm's body, making a ladder-shaped structure (Figure 13.3h). The brain is connected to the VNC by circumpharyngeal connectives, which surround the pharynx (Verdonschot 2015) (Figure 13.3h). Platynereis's brain contains prominent dorsal neuropile arrangements named mushroom bodies (Tomer et al. 2010), a structure shared with arthropods (Heuer et al. 2010). Interestingly, the mushroom body anlagen in Platynereis larvae expresses a similar molecular signature to developing mushroom bodies in Drosophila melanogaster, thus providing strong evidence in favor of an evolutionary relatedness of insect and annelid mushroom bodies (Tomer et al. 2010). Platynereis's brain is also an important neurosecretory center. Its developing forebrain expresses the neuropeptides FMRFa and vasotocin (Tessmar-Raible et al. 2007), plus a diversity of other neuropeptides recently identified, such as somatostatin, galanin and so on (Williams et al. 2017). Interestingly, this annelid brain region shares a common molecular signature with the vertebrate hypothalamus, furthering the hypothesis of an evolutionary relationship between those two structures (Williams and Nagy 2017). In addition, Platynereis's brain produces a brain hormone responsible for the switch from a growing juvenile to a sexually mature worm (Hauenschild 1956). This hormone, whose activity suppresses reproduction, was recently identified as Methylfarnesoate (Schenk et al. 2016). In addition to the brain, the VNC is also a complex structure that has been shown to harbor around 200 distinct types of neurons, expressing specific combinations of transcription factors in a small juvenile (Vergara et al. 2017). Platynereis's PNS is prominent in the head, being associated with the many sensory structures it contains. The PNS also contains the parapodial and pygidial nerve extensions. Indeed, the terminal part of the worm is highly innervated with nerve projections into the pygidium and the anal cirri (Starunov et al. 2015) (Figure 13.3h).

\subsubsection{Circulatory System}

Platynereis has a closed circulatory system mainly composed of two vessels and capillary networks. The dorsal and ventral vessels are connected by a capillary network forming a ring around the intestine. The dorsal pulsatile vessel is the main pump of the circulatory system, pumping the blood anteriorly (from the tail to the head), while the ventral vessel pumps the blood posteriorly. Segmental lateral vessels irrigate the parapodia in each segment in order to ensure their respiratory function (Saudemont et al. 2008; Verdonschot 2015). A circular blood sinus is present in the pygidium (Starunov et al. 2015).

\subsubsection{Musculature}

Platynereis has two main types of muscles, smooth and striated, which together ensure precise movements of the worm's body structures (Brunet et al. 2016) (Figure 13.3i). Some somatic striated muscles run longitudinally from the head to the tail of the animal. Additional somatic striated muscles control the movements of parapodia thanks to ventral oblique and parapodial fibers (Figure 13.3i). In contrast, visceral muscles are mainly smooth muscle (with the noticeable exception of the anterior part of the gut that contains striated visceral muscles). They form a specific muscular structure, the orthogon, which is composed of both circular and longitudinal fibers (Brunet et al. 2016). Smooth muscles are also associated with the pulsatile dorsal vessel (Brunet et al. 2016). A peculiar somatic striated and longitudinal muscle, the axochord, is found between the VNC and the dorsal vessel and is proposed to be at the origin of the chordate notochord (Lauri et al. 2014; Brunet et al. 2015). The pygidium musculature is also highly complex, mainly composed of a strong array of circular muscles that plays the role of the anal sphincter (Starunov et al. 2015).

\subsubsection{Excretory System}

Platynereis atoke worms possess in each segment, except the pygidium, a pair of metanephridia that connects the coelomic compartment to the exterior to ensure the excretion of waste products (Hasse et al. 2010; Verdonschot 2015). 


\subsubsection{Digestive System}

The digestive system of Platynereis is mainly composed of three successive elements called the foregut, the midgut and the hindgut (Fischer et al. 2010; Zidek et al. 2018). The foregut is composed of the mouth, the eversible pharynx and the jaws, in charge of collecting and grinding the food. Digestive enzymes are secreted and active in the midgut, where food absorption occurs. The last section of the digestive system is a hindgut connecting the midgut to the anus and producing digestive enzymes, too (Verdonschot 2015; Williams et al. 2015).

\subsubsection{External and Internal Anatomy of Platynereis dumerilit Adult (Epitoke) Worms}

As mentioned before, one of the main events in Platynereis life cycle is sexual maturation (epitoky), since it induces not only drastic morphological modifications but also changes in behavior (Fischer and Dorresteijn 2004). A striking difference between mature and juvenile worms is the difference in body color (Figure 13.3j and k): while juveniles mainly show a sex-independent brownish color, sexual dimorphism appears during epitoky, as females become bright yellow (Figure 13.3j) and males display white anterior and red posterior body regions (Figure 13.3k). During sexual maturation, worms stop food intake, their gut regresses and becomes non-functional. The trunk of the animal is progressively modified to become a "bag" full of gametes, visible through the body wall, which loses its pigmentation (Fischer and Dorresteijn 2004; Fischer et al. 2010). The yellow oocytes and white spermatozoids both contribute to the main color of the female and male anterior parts, respectively. Among other morphological changes, the eyes enlarge dramatically (Figure 13.31), and the homonomous segmentation present in juveniles is lost. Indeed, while anterior segments are not modified, posterior segments are substantially reshaped, and a clear boundary between these two parts of the trunk becomes visible (between the 15th and 20th segments, depending on the sex; Figure 13.3m) (Schulz et al. 1989; Fischer 1999). In modified posterior segments, parapodia flatten and develop paddle-shaped chaetae in both sexes. In males, posterior parapodia show a significant increase in vascularization, conferring its red color to the posterior part (Figure 13.3n). Muscles present in juvenile worms degenerate and are replaced by new muscle fibers which are specific to sexually mature animals. This dramatic reorganization of the body enables the formerly benthic juvenile worms to swim quickly to ensure the nuptial dance required for sexual reproduction (Fischer and Dorresteijn 2004; Fischer et al. 2010). Finally, while the terminal part of the female is not modified, the male pygidium presents extra papillae, allowing the sperm to be released in many directions (Figure 13.3o) (Starunov et al. 2015). In Platynereis, the switch from a growing worm to its reproductive life stage is controlled by brain hormone activity. Interestingly, worm decapitation (i.e. artificial reduction of brain hormone) induces worms' sexual maturation similarly to natural conditions (Schenk et al. 2016).

\subsection{EMBRYOGENESIS AND LARVAL DEVELOPMENT}

More than a century ago, Edmund B. Wilson retraced an incredibly relevant and reliable cell lineage of embryo blastomeres in order to depict the origin of the germ layers in annelids (Wilson 1892). To do so, he took advantage of the transparency of Nereis limbate (now Alitta succinea) and Nectonereis megalops (now Platynereis megalops) embryos and of their stereotypic development. Indeed, as all embryos develop in exactly the same way, they provide an ideal framework to link cell division to blastomere formation and cell fate. Interestingly, since publication, his work has been reasserted by the description of Platynereis dumerilli embryogenesis in the early 90s (Dorresteijn 1990), and his assumptions regarding blastomere cleavage and fate remain a reference in the field of annelid development. Indeed, micro-injection of individual blastomeres at different embryonic stages with fluorescent dyes has more recently confirmed previous observations (Fischer and Dorresteijn 2004; Ackermann et al. 2005). Hereafter, we have mainly compiled the previously mentioned publications to depict the main events of embryogenesis and larval development (Fischer et al. 2010).

\subsubsection{Embryo DeVelopment}

\subsubsection{Unfertilized Eggs}

Unfertilized eggs are packed within the coelomic cavity of the mature female, causing their polymorphous shapes. Upon laying, the pressure is released and the eggs rapidly undergo a massive shape change to become ellipsoid (the short axis of the unfertilized egg corresponds to the future animal-vegetal axis of the zygote). At that stage, their cytoplasm is organized, in a concentric fashion, around the central nucleus which is wrapped in yolk-free cytoplasm. The latter is surrounded by a shell of yolk containing large lipid droplets (in particular in the equatorial plane where they are bigger) and a thick outer layer of cortical granules (secretory organelles found within oocytes). Finally, the egg is itself protected within a vitelline envelope. Interestingly, in Platynereis, eggs are in fact oocytes blocked in metaphase and, as such, the release of polar bodies occurs after fertilization.

\subsubsection{Fertilization}

Upon fertilization, the fertilizing spermatozoid sticks to the cell surface until the emission of the first polar body (a small haploid cell). As soon as this contact is established, substantial changes in the cytoplasmic organization of the oocyte occur. The cortical granules are released to form an external jelly layer (0-23 minutes post-fertilization, mnpf). As a consequence, the yolk granules are less packed within the 
spherical egg and more broadly distributed, while the lipid droplet pattern remains as a readout of the equatorial plan. When the vitelline envelope breaks down (18 mnpf), a small area is progressively cleared from yolk at one pole of the egg compared to the equatorial location of lipid droplets. This area marks the future animal pole where the first polar body is formed (60 mnpf, Figure 13.4a). The sperm pronucleus finally enters into the ooplasm, and a second polar body is formed ( $80 \mathrm{mnpf})$. Yolk granules migrate toward the vegetal pole, allowing the rapid expansion of the clear cytoplasm, the female pronucleus forms and karyogamy (fusion of the two nuclei) occurs (90-100 mnpf). Subsequently, the animal pole is completely cleared from yolk granules, and the first cleavage is initiated.

\subsubsection{First Cleavages (120-420 mnpf)}

The first cleavage is unequal, giving rise to a small $\mathrm{AB}$ blastomere and a large CD blastomere (73\% of the volume, 100 mnpf, Figure 13.4b1). This unequal cleavage induces a new axis, perpendicular to the vegetal/animal axis, which nearly corresponds to the dorsoventral axis. The second cleavage is slightly asynchronous (Figure 13.4a), unequal in the CD blastomere (D blasomere inheriting 50\% of the total egg volume) and equal in the small $\mathrm{AB}$ blastomere (135 mnpf; Figure $13.4 \mathrm{a}, 4 \mathrm{~b} 2)$. Each of the resulting four macromeres is the founder of a distinct quadrant (e.g. A-quadrant corresponds to the offspring of A macromere). The third cleavage is slightly asynchronous as well (Figure 13.4a) and corresponds to the first "spiral" cleavage (clockwise), producing two batches of two nearly identical micromeres (1a and $1 \mathrm{~b}$ versus $1 \mathrm{c}$ and 1d) (170 mnpf, Figure 13.4b3). Before the fourth asynchronous cleavage (Figure 13.4a), yolk granules are segregated at the vegetal pole of each blastomere. As a result, after completion of the fourth cleavage (i.e. 16-cell stage), blastomeres $1 \mathrm{a}^{1-} 1 \mathrm{~d}^{1}$ contain less yolk than blastomeres $1 a^{2-1} d^{2}$. The latter are called the primary trochoblasts and give rise to the equatorial ciliated belt, or prototroch, of the trochophore larva (Figure 13.4b4). The $2 \mathrm{~d}$ blastomere is by far the largest micromere, since its size even exceeds that of the macromeres $2 \mathrm{~A}-2 \mathrm{C}$. After the fourth cleavage, cleavages become highly asynchronous (except in the trochoblasts), and the cleavage strategy of the D quadrant strongly differs from the others with the short cell cycle of $2 \mathrm{~d}^{1}$ and $4 \mathrm{~d}$ cell lines (Figure 13.4a). At the 38-cell stage, the fate of the three germ layers is established. The four macromeres (3A$3 \mathrm{C}$ and $4 \mathrm{D}$ ) give rise to the endoderm, and the mesoderm mainly arises from $4 \mathrm{~d}$ micromere (also called mesoblast or "M"), as well as the germ line. All other micromeres form the ectoderm (Figure 13.4a, 4b5 to 4b5"').

\subsubsection{Stereoblastula/Stereogastrula/ Protrochophore Larva (7-24 Hours Post-Fertilization of hpf)}

After the 38-cell stage, micromeres no longer undergo spiral cleavage but rather progressively follow a bilateral symmetry. They rapidly divide and initiate their epibolic movement toward the vegetal pole, thus covering macromeres. This movement of micromeres results in the final equatorial position of trochoblasts, thus forming the prototroch. At the vegetal pole, cells arising from the cleavage of the $4 \mathrm{~d}$ micromere submerge beneath the large cells produced by the $2 \mathrm{~d}$ micromere and start to form the mesodermal bands $\left(4 \mathrm{~d}^{122}\right.$ and $4 \mathrm{~d}^{222}$ lines the dorsal rim of the blastopore); gastrulation is thus initiated. In Platynereis, this process shows amphistome mode, meaning that the blastopore gives rise to both the mouth and the anus (Figure 13.4c) (Steinmetz et al. 2007). During this massive rearrangement of embryonic cells, the D-quadrant plays a key role, especially in the formation of trunk tissues. Indeed, the 4D blastomere participates in midgut anlage, and the $2 \mathrm{~d}$ offspring forms the somatic plate and the entire trunk ectoderm (i.e. epidermis and nervous system). The $4 \mathrm{~d}$ lineage provides the full trunk mesoderm, including the four quiescent putative primordial germ cells (i.e. $1 \mathrm{~mL}, 1 \mathrm{mr}, 2 \mathrm{~mL}$ and $2 \mathrm{mr}$ resulting from two asymmetric divisions of M-daughter cells) but also the cells composing the growth zone where new segments are added after the larval stage (Fischer and Arendt 2013; Ozpolat et al. 2017). During gastrulation and later on, the presence of four lipid droplets appears as a good readout of the proper development of the embryo. After the gastrulation stage, the embryo, often called the protrochophore larva (13-24 hpf), despite the persisting jelly, is slowly rotating within the jelly thanks to the prototroch (Figure 13.4c). It develops an apical tuft (apical ciliated organ), and the stomodeal field (i.e. the mouth anlage) starts to develop too. At around $17 \mathrm{hpf}$, the first serotonergic neuron differentiates at the posterior extremity of the protrochophore larvae (Starunov et al. 2017).

\subsubsection{Larvae Development}

\subsubsection{Trochophore Larva (24-48hpf)}

The trochophore larva is a phototactic swimming larva possessing two pigmented eyes that become more and more prominent (Figure 13.4c). With age, the spherical larva elongates, and three segments start to appear. Consistent with this first sign of segmentation, three pairs of ectodermal bulges develop laterally from $2 \mathrm{~d}$ descendants to form the ventral chaetal sac pairs (Figure 13.3c'). An additional band of ciliated cells, called the telotroch, is formed at the posterior end, marking the edge between the pygidium and the rest of the trunk ( $26 \mathrm{hpf}$ ). Regarding the establishment of the digestive tract, the number of stomodeal cells slightly increases, and they start to form a ring (i.e. the stomodeal rosette). The stomodeal field progressively moves toward the anterior pole, and the rosette opens just below the prototroch to form the mouth $(40 \mathrm{hpf})$. Meanwhile, the overall nervous system rapidly develops (also from $2 \mathrm{~d}$ micromeres) in part along with the increase in ciliated structures. From $24 \mathrm{hpf}$, various nervous connections are also implemented. Indeed, the apical ganglion at the posterior pole, containing the pioneer neuron of the $\mathrm{VNC}$, is linked to the prototroch nerve ring by two ventral connectives. These connectives of the 
(a)

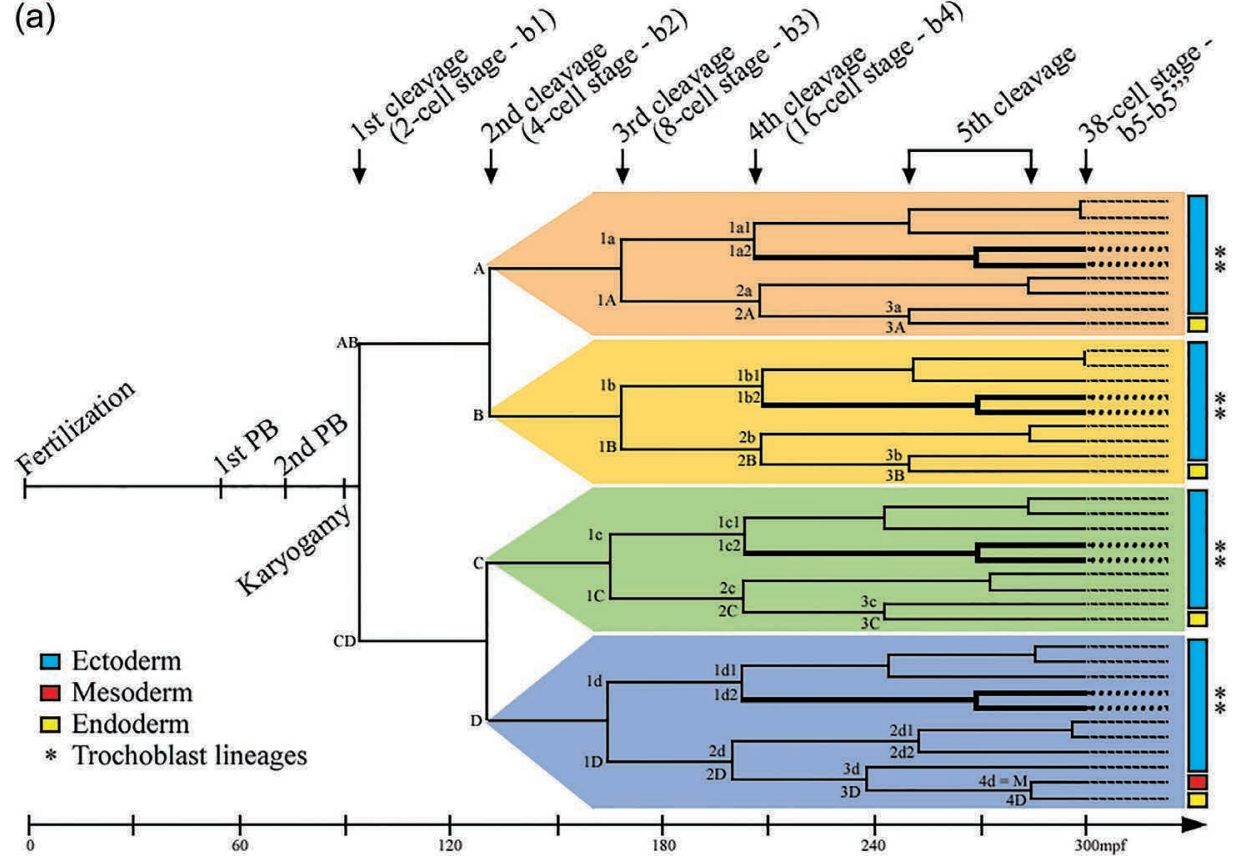

(b1)

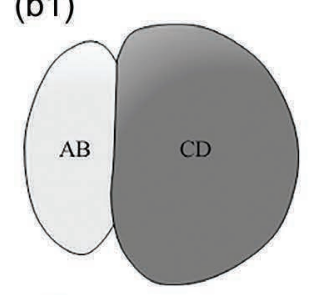

(b5)

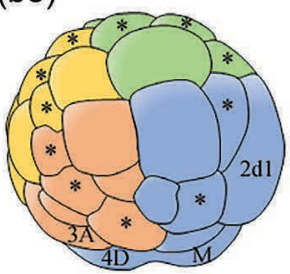

(c)

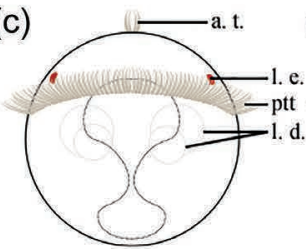

(b2)

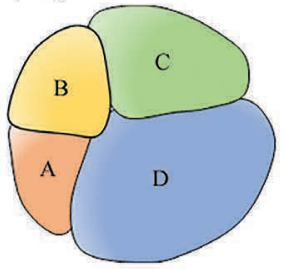

(b5')

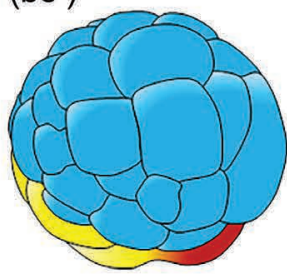

(c')

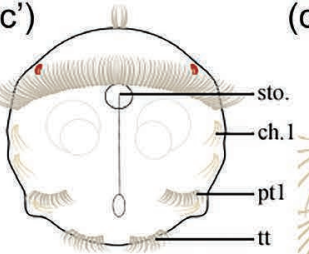

(b3)

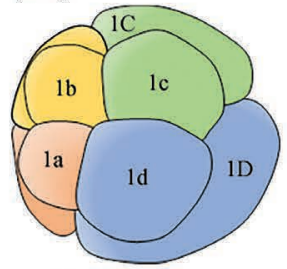

(b5")

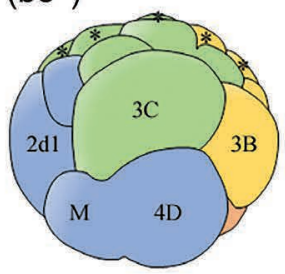

(b4)

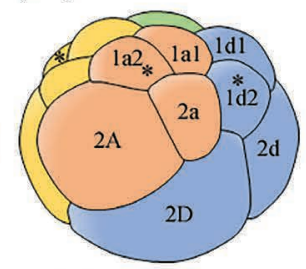

(b5"')

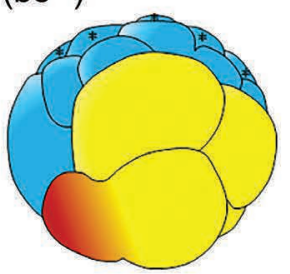

(c")

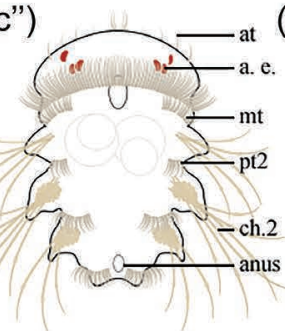

(c"')

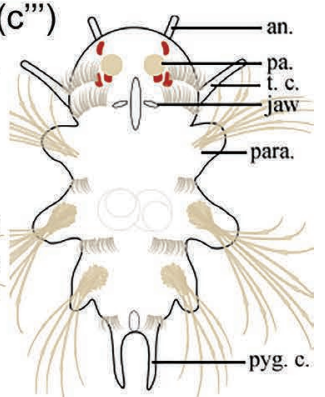

FIGURE 13.4 Embryogenesis and larval development in Platynereis dumerilii. (a) Dendrogram summarizing the stereotypic steps following fertilization, including the emission of the two polar bodies (PB), karyogamy and the first cleavages (see b1 to b5"') that give rise to a 38-cell embryo in which the fate of the three germ layers is established (see legend on the panel) as well as trochoblast lineages $\left(1 \mathrm{a}^{2-} 1 \mathrm{~d}^{2}\right)$. Colored backgrounds represent each quadrant (i.e. A, B, C and D). Blastomere names are provided above and below nodes (in capital letters for macromeres), including the highly proliferative $2 \mathrm{~d}^{1}$ and $\mathrm{M}$ micromeres. Time frame is provided below the dendrogram. (b1-b5"') Schematic representation of embryo following the five first cleavages. Color codes are similar to those in (a). (b1-b3, b5, b5') Animal views. (b4) Animal pole at the top. (b5", b5"') Vegetal views. Based on (Dorresteijn 1990). (c-c"') Schematic representation of larval development. Ventral view of (c) 24-hour post-fertilization (hpf) larva, (c') 48-hpf larva, (c") 72-hpf larva and (c"') 6-day post-fertilization larva. Abv: a. e. $=$ adult eye, an. = antenna, a. t. $=$ apical tuft, at $=$ akrotroch, ch. $1 / 2=$ chaeta within/outside the body wall, 1. e. $=$ larval eye, 1 . d. = lipid droplets, $\mathrm{mnpf}=$ minutes post-fertilization, $\mathrm{mt}=$ metatroch, para $=$ functional parapodia, $\mathrm{pa} .=\mathrm{palpa}, \mathrm{pt} 1 / 2=\mathrm{paratroch}$ 1 and $2, \mathrm{ptt}=$ prototroch, pyg.c. $=$ pygidial cirrus, sto. $=$ stomodeum, t.c. $=$ tentacular cirrus, $\mathrm{tt}=$ telotroch. $($ Based on Dorresteijn 1990.$)$ 
VNC represent the two first axons of the brain. Immediately thereafter, the dorsal root of the circumesophagial connectives develop as well, followed by the ventral root ( $26 \mathrm{hpf}$ ) to connect the VNC to the brain. At the same time, the single asymmetric unpaired dorsal axon and the first cerebral commissures appear. Later on, three additional serotoninergic cells arise at the apical part (30-34 hpf), as well as one pair at the first ventral commissure (40 hpf). Finally, the second ventral commissure appears (44 hpf) (Starunov et al. 2017). Similarly, muscles appear and develop during the trochophore stage. The dorsal longitudinal muscles develop first ( $28 \mathrm{hpf})$, followed by ventral longitudinal muscles ( $32 \mathrm{hpf})$, while the oblique and parapodial muscles start to be visible at the late trochophore stage (46-48 hpf). The excretory system appears also at the trochophore stage, with the emergence of small, lateral, non-ciliated tubules (Hasse et al. 2010).

\subsubsection{Metatrochophore Larva (48-66 hpf)}

The metatrochophore larval stage is marked by the appearance of the two adult eye pairs (Figure 13.4c"). In addition, the three first segments appear more defined due to the formation of non-functional parapodia and the significant growth of the chaetae outside the body wall (these segments are so called the chaetigerous segments). In addition, the first paratroch appears between the second and the third chaetigerous segments ( $48 \mathrm{hpf}$ ), and a second one is visible later on between the first and the second chaetigerous segments (56 hpf), thus participating in segment delimitation. Then, above the prototroch, an additional ciliated structure progressively develops - the akrotroch-close to the apical tuft (60 hpf). The stomodeal rosette size increases with an additional ring of cells $(52 \mathrm{hpf})$. The stomodeum invaginates, resulting in the larval foregut that elongates toward the posterior part. The nervous system also rapidly develops. A third commissure appears (48 hpf), and all commissures thicken (54 hpf). Axon projections from the VNC are observed laterally and redirected ventrally toward the surface. The circumesophagial connectives get closer to each other, and the prototroch nerve ring moves toward the brain. All these phenomena participate in the formation and growth of the brain $(52 \mathrm{hpf})$. Additionally, the number of serotonergic cells along the ventral nerve cord increases with the occurrence of three additional pairs. Finally, the ventral medial longitudinal muscle appears (56 hpf) and elongates up to the posterior border of the third segment. Similarly, oblique and parapodial muscles also elongate (Figure 13.4c"). Excretory system development continues as non-ciliated tubules elongate laterally toward the developing stomodeum (Hasse et al. 2010).

\subsubsection{Nectochaete Larva ( $66 \mathrm{hpf}-5 \mathrm{dpf})$}

The nectochaete larva corresponds to a major lifestyle transition. Indeed, the pelago-benthic larva starts crawling on the substrate thanks to functional parapodia and starts to eat. The sensory organs, including antenna, palps, tentacular antero-dorsal cirri and anal cirri, appear and develop (75 hpf) (Figure 13.4c"'). The trunk continues to elongate, providing a worm-like shape to the larva, and a constriction distinguishes the trunk from the head. The two adult eyes found on both sides of the head increase in size and become extremely close. Lipid droplets progressively move toward the posterior part. Ciliogenesis progresses with the establishment of the metatroch, an additional line of ciliated cells that develops below the prototroch and fuses with this latter on the lateral sides. The midgut forms, as well as the proctodeum (anal region), and the stomodeum/foregut continues to elongate toward the posterior part, resulting in a fully functional digestive tract $(75 \mathrm{hpf}-4 \mathrm{dpf})$. Furthermore, the jaws develop within the foregut ( $4 \mathrm{dpf}$ ) and a pair of primary teeth appears (5 dpf). Meanwhile, the brain continuously grows, the convergence of the circumesophagial connective roots progresses, axon numbers increase in connectives and commissures and additional serotonergic cells arise both in the ventral nerve cord (66-72 hpf) and in the brain (4-5 dpf). The overall musculature develops as well, especially around the stomodeum, to form the pharynx. Additionally, muscles and nerves associated with the development of antennae and cirri increase. Seventy-two-hpf larvae possess a pair of anterio-lateral non-ciliated tubules named "head kidneys" located close to the episphere. These larval structures are transitory, since they disappear before $96 \mathrm{hpf}$. In parallel, larval nephridia or protonephridia, formed from ciliated tubules and localized between segments, start to appear (Hasse et al. 2010).

\subsubsection{Young Errant Juvenile}

At this stage, the development of animals is no longer synchronous. Very young worms start to sequentially produce additional segments through posterior elongation, a process relying on a thin row of cells (presumably stem cells) that forms the segment addition zone (SAZ) in front of the pygidium (Gazave et al. 2013). Worms also lose several larva-specific features such as the prototroch, the apical tuft, larval eyes and lipid droplets. The excretory system is composed of segmented protonephridia until the worms reach the size of 20 segments, at which stage metanephridia appear (Hasse et al. 2010). In addition, the first chaetigerous segment fuses with the head. This important morphological transition, called cephalization, consists of the transformation of the first pair of parapodia into tentacular posterior-dorsal cirri and the progressive loss of chaetae. Finally, spinning glands develop and produce mucus, allowing worms to build their first cocoon network.

\subsection{GENOMIC DATA}

As in many animals, counting chromosomes during metaphase revealed that Platynereis dumerilii is diploid $(2 n=28)$ (Jha et al. 1995). More precisely, the Platynereis karyotype encompasses seven chromosome pairs showing a median arm ratio, while the seven other pairs show a sub-median ratio (Figure 13.5). Different regular staining techniques were used to further characterize chromosome pairs. For instance, Chromosome 2 shows a clear C-band-positive 


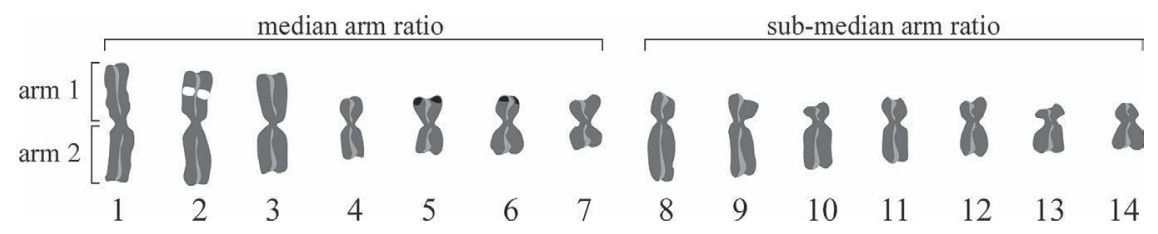

FIGURE 13.5 Schematic representation of Platynereis chromosomes. Platynereis possesses $2 n=28$ chromosomes, five pairs showing a median position of centromeres (Chromosome 1 to 7 ). Black and white areas represent heterochromatin (C-band-positive band) and ribosomal RNA genes (NOR staining), respectively.

region, revealing a constitutive heterochromatin region not localized at the centromic region. Nuclear organizer regions (NORs) are found at the terminal positions of Chromosomes 5 and 6 , thus revealing the localization of genes coding for ribosomal RNA.

The precise genetic content of these chromosomes is in the course of being uncovered. Indeed, the Platynereis dumerilii genome has recently been sequenced by the D. Arendt laboratory (EMBL, Germany), notably from sperm. Although this genome is currently being refined with the aim of obtaining a chromosome-level assembly, a highquality draft version is already available, upon request, for the whole community working on Platynereis. Preliminary data revealed that Platynereis genome appears less compact than in other annelids ( 1 Gpb) (Zantke et al. 2014), and a previous analysis comparing bacterial artificial chromosome (BAC) sequencing and expressed sequence tags (ESTs) on a subset of 30 randomly detected genes suggested that Platynereis genes are intron rich, surprisingly, with two-thirds of introns shared between Platynereis and human orthologs (Raible et al. 2005). Various additional transcriptomic databases have been acquired during the past years (Table 13.1), including bulk RNA-seq data for all key stages of embryonic and larval development, juveniles of different ages and adults (Conzelmann et al. 2013; Chou et al. 2016). These data have been grouped together and are now publicly available on the Pdumbase website (Chou et al. 2018) (http://140.109.48.81/platynereis/controller. php?action=home). Platynereis is being actively studied by a scientific community, notably in the field of evolution and developmental biology, and as such, additional transcriptomic databases are constantly produced. For instance, Achim and collaborators shed light on the transcriptomic landscape of cell diversity in 48 hpf-larvae using a singlecell RNA-seq (scRNA-seq) approach (Achim et al. 2015; Williams et al. 2017; Achim et al. 2018). In addition, bulk RNA-seq were acquired to unravel the dynamic of gene expression during circalunar-dependent sexual maturation (Schenk et al. 2019) and posterior regeneration (Vervoort's Lab, unpublished data).

Finally, in addition to the significant Platynereis resources acquired during the past decade, the availability of genome sequences of the Sedentaria Capitella teleta, Helobdella robusta (Simakov et al. 2013), Spirobranchus lamarcki (Kenny et al. 2015), Lamellibrachia luymesi (Li et al. 2019), Eisenia Andrei (Shao et al. 2020) and Eisenia fetida (Bhambri et al. 2018) as well as the Dinophiliformia (sister group to Sedentaria + Errantia) Dimorphilus gyrociliatus (Martin-Duran et al. 2021) allow for comparative analyses within annelids.

\subsection{FUNCTIONAL APPROACHES: TOOLS FOR MOLECULAR AND CELLULAR ANALYSES}

In addition to its scientific relevance and its easy maintenance in laboratory, the success of Platynereis as a new model system also strongly relies on the efforts that have been undertaken to develop a large panel of molecular and cellular tools to successfully tackle interesting biological questions in evolutionary and developmental biology (Backfisch et al. 2014; Williams and Jekely 2016).

\subsubsection{Descriptive Approaches}

\subsubsection{Detection of mRNA: Whole- Mount In Situ Hybridization}

As mentioned in the genomic data section, several highquality bulk RNA-seq and scRNA-seq were recently used to investigate modulations in gene expression during various processes in Platynereis. Nevertheless, bulk RNA-seq average information from various cell populations and scRNA-seq remains expensive, and their interpretation relies on a comprehensive description of cell populations in vivo. Accordingly, despite important breakthroughs in sequencing technologies, whole-mount in situ hybridization (WMISH) remains an indispensable molecular approach to localize gene expression. WMISH has been established in Platynereis to investigate gene expression during early embryonic/larval stages (Arendt et al. 2001), posterior elongation (Prud'homme et al. 2003, Gazave et al., 2013), regeneration (Planques et al. 2019) and the adult stage (Backfisch et al. 2013) using the regular NBT/BCIP colorimetric staining (Figure 13.6a and a'). Similarly, fluorescent in situ hybridization (FISH, Figure 13.6b and b') has been established (Tessmar-Raible et al. 2005), while current efforts are now also dedicated to implement hybridization chain reactions (HCRs) (Choi et al. 2018), thus allowing multiple transcript detection to be required for co-expression analysis. Finally, the stereotypic development of embryo and larva coupled with in situ hybridizations allows for image registration (Figure 13.6c), which consists of a virtual atlas of expression patterns for their systematic comparison (Tomer et al. 2010; Asadulina et al. 2012). 
TABLE 13.1

Platynereis genomic (BAC) and transcriptomic (EST and RNA-seq) databases

\begin{tabular}{|c|c|c|c|c|c|}
\hline \multicolumn{2}{|r|}{ Stage } & \multicolumn{2}{|c|}{ Sequencing information } & \multirow{2}{*}{$\begin{array}{l}\text { Repository } \\
\text { Genbank: CT030666 } \\
\text { - СТ030681 }\end{array}$} & \multirow{2}{*}{$\begin{array}{l}\text { References } \\
\text { Raible et al., } 2005\end{array}$} \\
\hline U & Sperm of mature Male & Sanger (shotgun) & 15 contigs & & \\
\hline \multirow{2}{*}{ 点 } & Larvae (48hpf) & Sanger (3730xl) & $\begin{array}{l}1,484 \text { expressed sequence } \\
\text { tags }\end{array}$ & $\begin{array}{l}\text { Genbank: CT032248 } \\
\text { - CT033731 }\end{array}$ & Raible et al., 2005 \\
\hline & Larvae and juvenile stages & Sanger + 454 Roche & $\begin{array}{l}77,419 \text { expressed sequence } \\
\text { tags }\end{array}$ & $\begin{array}{l}\text { Genbank: JZ391525 } \\
\text { - JZ468943 }\end{array}$ & $\begin{array}{l}\text { Conzelmann et al., } \\
2013\end{array}$ \\
\hline \multirow{3}{*}{ 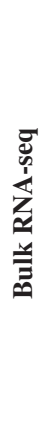 } & $\begin{array}{l}\text { Fertilized eggs, larvae ( } 24 \text {, } \\
36,48,72 \mathrm{hpf} \text { and } 4 \mathrm{dpf}) \\
\text { juveniles (10, } 15 \mathrm{dpf}, 1, \\
3 \mathrm{mpf} \text { ) and adults (males } \\
\text { and females) }\end{array}$ & Illumina (HiSeq 2000) & $\begin{array}{l}351,625 \text { reads, } 87,686 \text { contigs } \\
\text { (>500bp), 28,067 }(>1000 \mathrm{bp}) \text {, } \\
51,767 \text { ORFs }(>120 \mathrm{aa})\end{array}$ & Supp. Data & $\begin{array}{l}\text { Conzelmann et al., } \\
2013\end{array}$ \\
\hline & $\begin{array}{l}\text { Embryonic development }(2,4 \text {, } \\
6,8,10,12 \mathrm{hpf}) \text { and larvae } \\
(14 \mathrm{hpf})\end{array}$ & Illumina (HiSeq) & $\begin{array}{l}273,087 \text { contigs, } 51,260 \text { ORFs } \\
(>100 \mathrm{aa})\end{array}$ & $\begin{array}{l}\text { https://github.com/ } \\
\text { hsienchao/pdu_sqs/ } \\
\text { find/master }\end{array}$ & Chou et al., 2016 \\
\hline & $\begin{array}{l}\text { Head samples under various } \\
\text { circalunar conditions and } \\
\text { maturation stages }\end{array}$ & Illumina (HiSeq 2000) & 52,059 contigs $(>500 \mathrm{bp})$ & $\begin{array}{l}\text { ENA repository: } \\
\text { PRJEB27496 }\end{array}$ & Schenk et al., 2019 \\
\hline \multirow{2}{*}{ 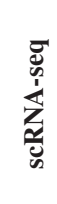 } & 47hpf-larva epispheres & \multicolumn{2}{|c|}{$\begin{array}{l}\text { Fluidigm C1 Single-Cell Auto Prep System / Illumina } \\
\text { (HiSeq 2000) }\end{array}$} & $\begin{array}{l}\text { ArrayExpress: } \\
\text { E-MTAB-2865 }\end{array}$ & Achim et al., 2015 \\
\hline & 48hpf-larvae & \multicolumn{2}{|c|}{$\begin{array}{l}\text { Fluidigm C1 Single-Cell Auto Prep System / Illumina } \\
\text { (HiSeq 2000) }\end{array}$} & $\begin{array}{l}\text { ArrayExpress: } \\
\text { E-MTAB-2865 and } \\
\text { E-MTAB-5953 }\end{array}$ & Achim et al., 2018 \\
\hline
\end{tabular}

$B A C=$ bacterial artificial chromosome sequencing; $E S T=$ expressed sequences tags

\subsubsection{Detection of Proteins: Immunohistochemistry and Western Blot}

The in vivo detection of proteins has been developed as well. The first detection of proteins in Platynereis dates back to the early 90 s with the visualization of the nervous system, ciliated cells and the entire epidermis during early development using various antibodies (Abs) raised against Nereis diversicolor (Annelida) proteins, Drosophila Engrailed and Antennapedia, respectively (Dorresteijn et al. 1993). Since then, antibodies such as those against acetylated-Tubulin Abs are now routinely used to depict the Platynereis nervous system (Figure 13.6d). In contrast to WMISH that can be performed on virtually all genes, immunohistochemistry (IHC) suffers from the lack of appropriate Abs developed against Platynereis proteins (or proteins from closely related species). Accordingly, WMISH remains the preferred approach used as a proxy of protein location, while IHC is often restricted to highly conserved proteins (e.g. proteins from the cytoskeleton and histones). Nevertheless, IHC against other proteins such as MIP peptides, $\beta$-catenin or neuropeptides have also proven successful (Schneider and Bowerman 2007; Conzelmann et al. 2011; Williams et al. 2015; Gazave et al. 2017). Western blots (WBs) have been also developed from whole cell extract (Schneider and Bowerman 2007) and nuclear extracts (Figure 13.6e, unpublished data Vervoort's Lab), thus allowing for the quantification of specific proteins in different tissues or upon various conditions.

\subsubsection{Tracking Cell, Cell Components and Monitoring Key Cellular Processes}

Staining approaches: Various staining using commercially available dyes were used to study, for instance, muscles (phalloidin) or chaetae (wheat germ agglutinin) or to stain cell membranes (mCLING-ATTO 647N, FM-464) either on fixed or live animals, depending on the dye used (Lauri et al. 2014; Williams et al. 2015; Gazave et al. 2017; Chartier et al. 2018). Staining to monitor key cellular processes has also been developed in Platynereis. For instance, EdU (5-ethynyl-2'deoxyuridine, Figure 13.6f and f') and BrdU (Bromo-desoxyuridine) incorporations followed by chasing are used to highlight proliferative cells and their progenies, a key approach to characterize putative stem cells / progenitors and their lineage during early development (Rebscher et al. 2012; Demilly et al. 2013), posterior elongation (Gazave et al. 2013) and regeneration (Planques et al. 2019). Cell death can be assessed as well, using real-time apoptosis detection (TUNEL) (Demilly et al. 2013; Lauri et al. 2014; Zidek et al. 2018).

Microinjection of dyes: As reported in the "Embryogenesis and Larval Development" section, Ackermann and colleagues injected Platynereis embryos at the two-, four- and eight-cell stages with fluorescent dyes (e.g. FITC-dextrane) to trace blastomere lineages and their respective contribution to tissue in young worms (Fischer and Dorresteijn 2004; Ackermann et al. 2005). 
(a)
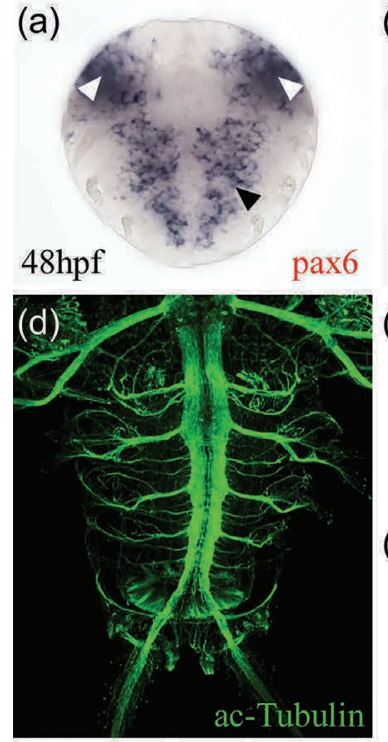

(a')

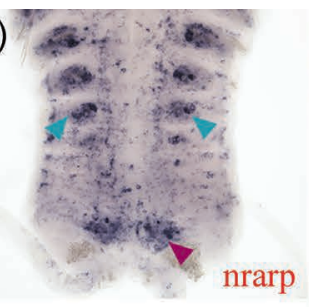

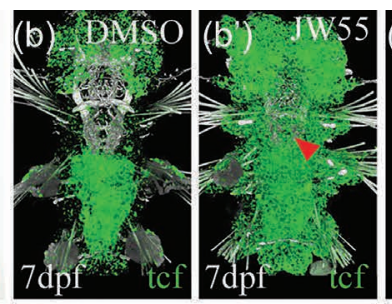

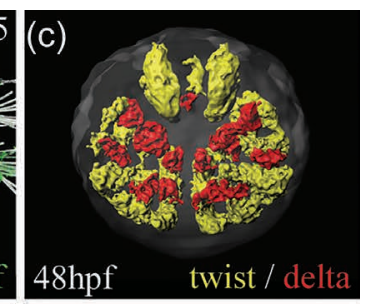

(e)
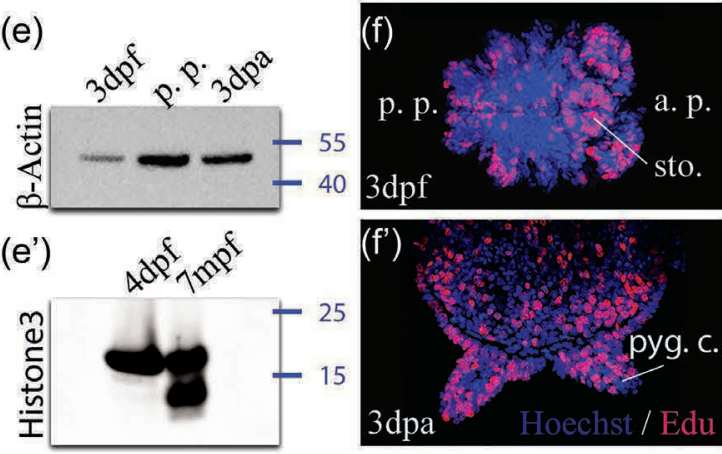

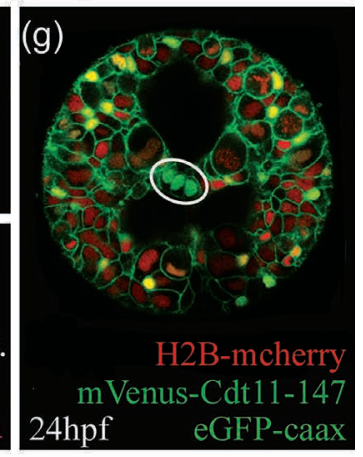

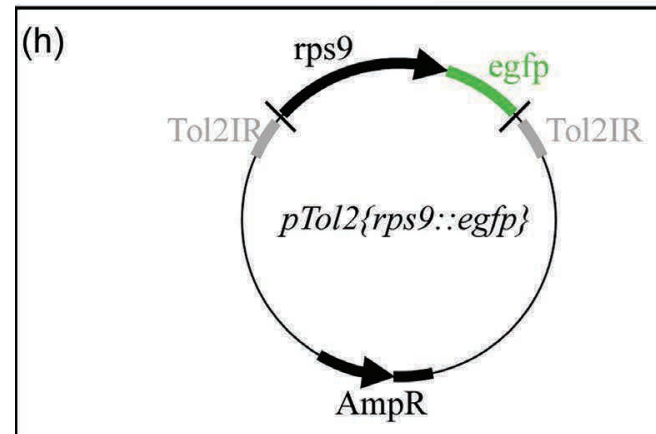
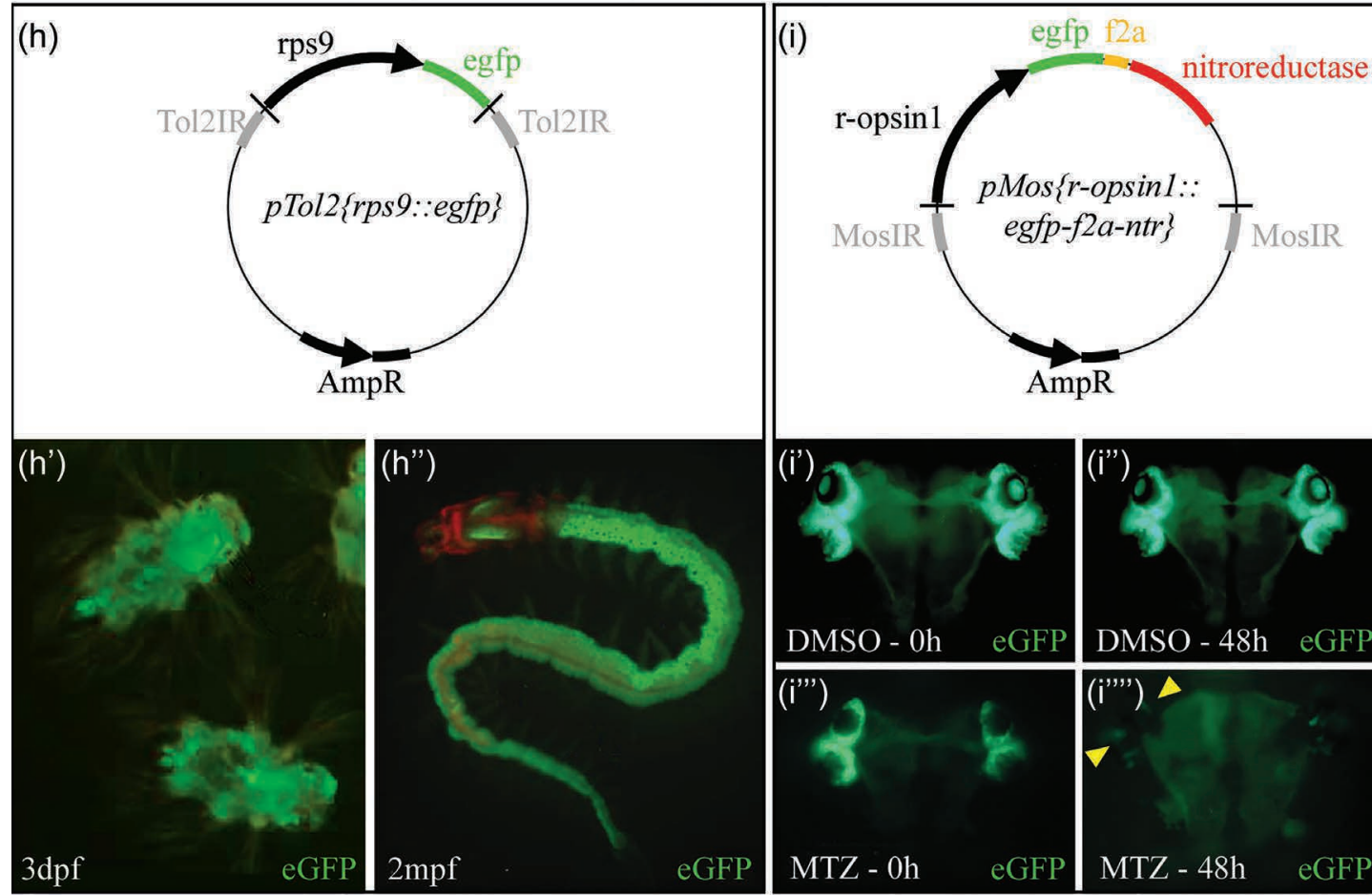

\section{(i)}
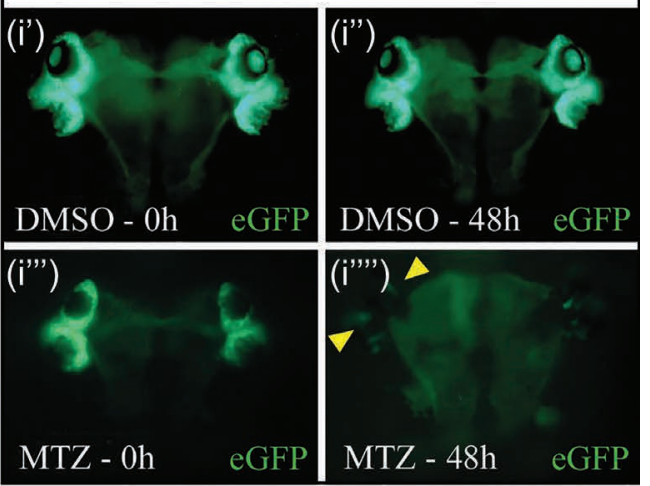

FIGURE 13.6 Molecular and cellular tools for functional approaches in Platynereis. (a-a') Whole-mount in situ hybridizations using NBT/BCIP colorimetric staining showing (a) the expression pattern of pax6 in brain hemispheres (white arrowheads) and ventral neurectoderm (black arrowhead) and (a') nrarp expression in chaetal sacs (blue arrowheads) and cells of growth zone (purple arrowhead) during posterior elongation. (b-b') Fluorescent in situ hybridization showing the effect of Wnt/ $\beta$-catenin pathway inhibition on $t c f$ expression. Upon JW55 treatment (Axin2 stabilization), $t c f$ expression is extended to other tissues (red arrowhead) in addition to its regular expression in brain ganglia and midgut. (c) Image registration showing Platynereis twist and delta expressions in mesoderm and chaetal sacs, respectively. Ventral view. (d) Acetylated-Tubulin immunohistochemistry revealing the ventral nervous system in posterior part. (e-e') Western blot of Platynereis using (e) whole cell extracts ( $\beta$-Actin) and (e') nuclear extracts (Histone 3). (f-f') EdU staining to investigate proliferative cells (f) in larva and (f') posterior part regeneration. (g) Co-injection of H2B-mcherry (nuclear marker), mvenuscdt11-147 (cell cycle biosensor) and egfp-caax (membrane marker) mRNAs in fertilized embryo used to follow cell cycle progression during embryo development. The green staining of putative primordial germ cells (white circle) suggests that they no longer divide (Ozpolat et al. 2017). (h-h") Tol2 transposase system for transient transgenesis using the promoter of the ribosomal protein Rps9 (rps9) to ubiquitously express enhanced green fluorescent protein (egfp) (h') in larvae and (h') young worms. (i-i'",') Mos transposase system for heritable transgenesis using the promoter of $r$-opsin1 to co-express egfp and bacterial nitroreductase in (i') adult eyes. (i'-i',') Upon metronidazole 48h-treatment (MTZ), Nitroreductase converts MTZ into a toxic compound leading to the death of positive cells (yellow arrowheads). Abv: a. p. = anterior part, dpa = days post-amputation, $\mathrm{hpf} / \mathrm{dpf} / \mathrm{mpf}=$ hours $/$ days $/$ month post-fertilization, $\mathrm{p} . \mathrm{p} .=\mathrm{posterior}$ part, pyg. c. $=$ pygidial cirrus, sto = stomodeum. $([\mathrm{b}-\mathrm{b}$ '] Zidek et al. 2018; [h"'] Backfisch et al. 2014; [i'-i"','] Backfisch et al. 2014.) 
Microinjection of mRNA: mRNA were also successfully injected into fertilized embryos to induce the expression of different fluorescent proteins such as the photoactivable mCherry (PAmCherryl) and the photoconvertible Kikume Green-Red (KIKGR) protein for cell tracking (Lauri et al. 2014; Veraszto et al. 2017), biomarkers to mark nucleus (H2A-mCherry; H2B-eGFP) and cell membranes (egfpcaax; $m$ Yfp) (Lauri et al. 2014; Ozpolat et al. 2017; Kuehn et al. 2019) or biosensors to monitor cell cycle progression (mVenus-cdt1 $^{\text {aal-147 }}$ ) (Ozpolat et al. 2017) (Figure 13.6g) and neuronal activity (GCaMP6, calcium imaging) (Veraszto et al. 2017; Chartier et al. 2018) in live animals.

Transposon-based transgenesis of reporter cassettes: While mRNA represent an incredible useful technique for biomarker and biosensor expression during early development, transgenic animals allow for a tight control of gene expression. In Platynereis, two transposon-mediated systems (i.e. Tol2 and Mos-based constructs) were efficiently developed for both transient and stable transgenesis (Backfisch et al. 2014). To implement this approach, the promoter of the ribosomal protein Rps9 has been used to drive ubiquitous expression of the enhanced green fluorescent protein (egfp) (Figure 13.6h to h"). Interestingly, comparison of Tol2- and Mos-based systems using similar constructs [i.e. pTol2(rps9::egfp) and pMos(rps9::egfp)] revealed that whereas embryos injected with Tol2-based plasmids tend to show a higher frequency of genome integration than those injected with Mos-based plasmids, transgenes are heritable to progeny only through Mos-mediated transgenesis (Backfisch et al. 2014). Additional promoters to rps 9 have been developed to target specific cell populations such as the r-opsinl promoter for adult eye cells and their neuronal projections (Backfisch et al. 2013; Veedin-Rajan et al. 2013) (Figure 13.6i to i'), a specific alphatubulin promoter (tuba) for cells with motile cilia in larvae, a maf promoter for a subtype of nerve cells in the larval brain (Backfisch et al. 2014) and a guanylyl cyclase- $\beta$ promoter for the cholinergic motorneurons (Veraszto et al. 2017).

Serial section transmission electron microscopy (ssTEM): By imaging and assembling numerous serial sections (around 1,700 sections for a head and the first chaetigerous segment or 5,000 sections for a full individual) and manually tracing all neurons, researchers were able to reconstruct a comprehensive three-dimensional cell atlas of the visual neuronal circuit in $72 \mathrm{hpf}$ larvae, including 106 neurons (i.e. photoreceptor cells, interneurons and motoneurons) and their synaptic connectivity (Randel et al. 2014; Randel et al. 2015). This sophisticated approach has been more recently extended to other circuits such as the neurosecretory connectome (Williams et al. 2017).

\subsubsection{Functional Approaches}

\subsubsection{Gene Knock-Down: Translation- Blocking Morpholinos}

Although they are used infrequently, morpholinos (MOs) represent an interesting knock-down approach to assess gene functions during early development. In a study aiming to show the implication of myoinhibitory (MIP) peptides on larval settlement, two MIP-receptor MOs were successfully used. Indeed, in embryos injected with MOs, MIP treatmentinduced settlement was no longer observed (Conzelmann et al. 2013).

\subsubsection{Protein Inhibition/Activation: Pharmacological and Peptide Treatments}

Although concerns regarding putative off-target effects have been raised with the pharmacological approaches, often addressed by the use of different molecules in parallel, the treatment using inhibitors is an easy approach to assess the function of specific proteins in live animals, especially in water-dwelling animals such as Platynereis. In addition, this approach allows researchers to interfere with proteins at specific timepoints and during processes that cannot be reached using MOs (e.g. post-larval and regeneration processes). Accordingly, a broad range of studies has developed this approach, for instance, to investigate the function of key signaling pathways such as Wnt $/ \beta$-catenin (Schneider and Bowerman 2007; Steinmetz et al. 2007; Demilly et al. 2013; Marlow et al. 2014; Zidek et al. 2018) (Figure 13.6b and b'), Planar cell polarity (Steinmetz et al. 2007), Notch (Gazave et al. 2017) or Hedgehog (Dray et al. 2010) or to assess the role of key cellular processes such as cell proliferation (Planques et al. 2019). Similarly, successful results were obtained by incubating Platynereis larvae with zebrafish BMP4 peptides (Denes et al. 2007), Platynereis synthetic neuropeptide (Conzelmann et al. 2011) or Platynereis synthetic MIB peptides (Conzelmann et al. 2013; Williams et al. 2015).

\subsubsection{Genome Editing}

Transgenesis: Transgenesis in Platynereis has so far mainly been used to monitor gene expression and to study specific cell populations (see previously). However, this technique now opens a broad range of subsequent functional approaches, including conditional knock-down and ectopic expression. In Platynereis, transgenesis has been used for effective targeted cell ablation. Indeed, the use of $r$-opsin 1 promoter allowed the expression of the bacterial nitroreductase enzyme (Ntr) in Platynereis adult eyes (Veedin-Rajan et al. 2013). This enzyme converts metronidazole (MTZ) into a toxic product that induces the death of the corresponding cells (Figure 13.6i to i'"'). Thus, transgenic animals expressing nitroreductase represent a great alternative to laser ablation to specifically remove a subset of cells.

Transcriptional activator-like nuclease (TALEN): In Platynereis, TALEN has been established as an efficient tool to induce heritable mutagenesis (Bannister et al. 2014), and this approach has been recently used to highlight the involvement of gonadotropin-releasing hormone $(\mathrm{GnRH}$, known to integrate environmental stimuli for vertebrate sexual maturation and breeding) in the regulation of growth and sexual maturation by lunar phases. Indeed, maturation, growth and regeneration were reduced in animals where mutations leading to corazoninl/gnrhll knock-outs were performed (Andreatta et al. 2020). 
CRISPR/Cas9: CRISPR/Cas9 also has recently been used in Platynereis. In planktonic larvae, the startle response is mediated by collar receptor neurons expressing polycystin genes (PKD1-1 and PKD2-1). Interestingly, this freezing response is abolished in both PKD1-1 and PKD2-1 mutants (Bezares-Calderon et al. 2018).

\subsection{CHALLENGING QUESTIONS}

Platynereis has been successfully developed as a powerful marine model thanks to the development of many tools (see Section 13.7), allowing researchers to address a variety of biological questions, mostly related to evolutionary developmental biology (Ferrier 2012). Several of these questions have already been raised earlier in this chapter and have been the subject of detailed recent reviews, notably (i) biological rhythms and clocks (Tessmar-Raible et al. 2011; Raible and Falciatore 2014; Raible et al. 2017; Andreatta and Tessmar-Raible 2020), (ii) neuronal connectomics and plankton behavior (Jekely et al. 2018; Williams and Jekely 2019; Bezares-Calderon et al. 2020; Marinkovic et al. 2020) and (iii) cell type evolution (Brunet et al. 2015; Arendt, Musser et al. 2016; Arendt, Tosches et al. 2016; Arendt 2018; Nielsen et al. 2018; Arendt et al. 2019). Here, we choose to introduce two additional lines of research that are currently (re)emerging: the regeneration processes and epigenetic modifications during embryonic and postembryonic development.

\subsubsection{Regeneration}

Animal regeneration is defined as the ability to restore a lost or damaged body part (Poss 2010). This fascinating process has intrigued scientists for centuries, and we recently observed a strong re-emergence of the regeneration field thanks to the availability of new tools for less conventional models (Gazave and Rottinger 2021). Injury-induced regeneration is a widespread phenomenon harbored by species of all the major lineages of Metazoa. In addition, the extent of what can be regenerated after an injury greatly varies among animals (Grillo et al. 2016; Bideau et al. 2021). The origin and evolution of animal regeneration is a longstanding debate, and the questions of why and how regeneration abilities evolved are still poorly understood (Bely 2010). Annelids show amazing regenerative capabilities, as most species are able to regenerate the posterior part of their body and their parapodia following an amputation, as well as, for some species, their anterior part (including the head) (Ozpolat and Bely 2016). Experimental and descriptive morphological studies of annelid regeneration have provided important knowledge (Boilly 1969a, 1969b) (for recent reviews, see Kostyuchenko and Kozin 2020; Nikanorova et al. 2020). Nowadays, some cellular and molecular aspects of these processes have been addressed in a limited number of models (Myohara 2012; Sugio et al. 2012; de Jong and Seaver 2018; Ribeiro et al. 2019), notably Platynereis (Planques et al. 2019).
Platynereis is able to regenerate its posterior part as well as various body outgrowths, such as tentacles and parapodia, but not its head. Its posterior regeneration was recently carefully described at the morphological, cellular and molecular levels (Planques et al. 2019). After amputation of the posterior part of their body (segments, growth zone and pygidium), Platynereis worms rapidly regenerate both the posterior-most part of the body, the pygidium and the stem cell-rich growth zone, the latter then producing new segments through posterior elongation (Gazave et al. 2013). Interestingly, both complex differentiated structures and stem cell populations are regenerated during this event (Gazave et al. 2013). In precise conditions of worm age/size and a specific amputation procedure, Platynereis posterior regeneration follows five well-defined stages, which correspond to particular timepoints after amputation. Briefly, (i) wound healing is achieved one day post-amputation (1 dpa); (ii) a proliferating blastema appears around $2 \mathrm{dpa}$; (iii) at 3 dpa, this blastema shows a conspicuous antero-posterior and dorso-ventral organization; (iv) a well-differentiated pygidium is formed at $4 \mathrm{dpa}$; and (v) from $5 \mathrm{dpa}$, new morphologically visible segments are produced by the growth zone (Planques et al. 2019). While several parameters such as the size of the worms, the position of amputation, and the realization of serial amputations affect the timing of the process, posterior regeneration is always successful (except when the amputation is performed close to the pharynx and in sexually mature animals). Further characterization of posterior regeneration using various labelings and in situ hybridizations for tissue patterning genes indicates that regeneration is a rapid process: important cell and tissue differentiation starts at $3 \mathrm{dpa}$, and at this stage, the growth zone is already re-established and starts to produce segments. Thanks to EdU incorporations, cell cycle marker labelings and the use of an inhibitor of cell divisions, it has been also shown that cell proliferation is strictly required for regeneration (Planques et al. 2019). These findings pave the way for a better understanding of Platynereis posterior regeneration, while many pressing questions remain unanswered.

An important question in the regeneration field concerns the initiation and control of regeneration (Ricci and Srivastava 2018). Recent studies have suggested that cell death could be a crucial event by triggering cell proliferation (Perez-Garijo and Steller 2015). Cell death seems to be itself stimulated by the production of reactive oxygen species (ROS), essential for regeneration in several models (Hydra, Drosophila and so on) through the activation of various signaling pathways (Vriz et al. 2014). Whether the cascade ROS $\rightarrow$ apoptosis $\rightarrow$ proliferation may represent a general principle of regeneration is, however, not known. In annelids, this question has not been addressed yet, but preliminary data for Platynereis strongly suggest the occurrence of cell death at 1 and $2 \mathrm{dpa}$, concomitantly with a peak of cell proliferation (unpublished data).

Thanks to recently developed tools for molecular and cellular analyses in Platynereis, it is now possible to characterize the in vivo distribution of apoptotic cells and to detect 
the ROS production cells using fluorescent dyes or genetically encoded biosensors (Vullien et al. 2021). This in-depth description of the processes at play, combined with functional tools and transcriptomic analysis, will certainly in the near future uncover the initiation and control mechanisms of Platynereis posterior regeneration.

Another key question is to determine the origin and fate of blastema cells, which give rise to the regenerated structures (Morgan 1901; Tanaka 2016). They can derive from pre-existing stem cells present in the body before the amputation and/or being produced by dedifferentiation of cells at the amputation site (Tanaka and Reddien 2011). These cells could be pluripotent stem cells and/or more tissue-restricted progenitor cells with limited potency. In annelids, the source of cells involved in posterior and anterior regeneration has been partially addressed in a couple of species, such as Nereis diversicolor (Boilly 1969c), Enchytraeus japonensis (Myohara 2012; Sugio et al. 2012) or Capitella teleta (de Jong and Seaver 2018). During Platynereis posterior regeneration, EdU pulse and chase experiments strongly support the idea that blastema cells mostly derive from dedifferentiation of cells coming from the segment abutting the amputation plane, with the notable exception of the gut, which probably regenerates from pre-existing gut stem cells (Planques et al. 2019). In addition, blastema cells from very early stages express a collection of genes belonging to the GMP signature (Juliano et al. 2010), whose orthologs in other species are expressed in pluripotent/multipotent somatic stem cells and primordial germ cells. This suggests that blastema may contain multi- or pluripotent progenitors/stem cells, even if this needs to be confirmed. To better assess the origin and fate of blastema cells, it would be highly valuable to perform blastema cell lineage tracing experiments. This would allow us to clearly define the respective contribution of resident stem cells and local dedifferentiation events to blastema formation in Platynereis as well as the fate of blastema cells.

\subsubsection{Epigenetic Modifications during Embryonic/ Larval Development and Regeneration}

Development and regeneration are highly dynamic processes both requiring important changes in gene expression to handle the establishment of various cell populations (Gerber et al. 2018; Cao et al. 2019; Pijuan-Sala et al. 2019; Shao et al. 2020). This cell fate trajectory, allowing cells to progressively acquire their molecular and functional identities, implies dynamic modulations of epigenetic marks. Nowadays, in developmental biology and cell biology, epigenetics includes any alteration of gene expression that is not associated with changes in the DNA sequence but is due to other molecular mechanisms such as changes in the chromatin structure, histone post-translational modifications and non-coding RNAs (Nicoglou and Merlin 2017). By revealing how each locus is activated or downregulated, epigenetics represents a tremendous step forward by allowing comprehensive overviews of biological processes. Among epigenetic marks, DNA methylation (5-methyl-cytosine, $5 \mathrm{mC}$ ) appears to be the most extensively studied one (Greenberg and Bourc'his 2019). Basically, two different DNA methylation patterns exist, both occurring at $\mathrm{CpG}$ sites (CG motif in the DNA sequence) (Zemach et al. 2010). On the one hand, high levels of methylation at $\mathrm{CpG}$ islands (DNA regions where $\mathrm{CpG}$ sites are abundant) of promoter regions tends to be associated with low gene expression, while low methylation corresponds to active genes. Although this regulatory-promoter methylation is well identified in vertebrates, only few cases have been reported in non-vertebrates so far (de Mendoza et al. 2019). On the other hand, gene body methylation (GBM, i.e. methylation on coding regions, exons and introns) is found in vertebrates, non-vertebrate animals and other multicellular organisms (Suzuki and Bird 2008; Zemach et al. 2010). However, the function of this type of methylation remains largely unknown. Beyond DNA methylation, epigenetics also strongly relies on Histone mark modifications (e.g. acetylation, methylation, phosphorylation, ubiquitination). For instance, the study of Histone methylation and acetylation in vertebrates allowed researchers to describe specific marks of active and inactive genes (Karlic et al. 2010; Dai and Wang 2014). Among them, Histone 3 (H3) tri-methylation (me3) at lysine 4 (H3K4me3), H3K36me and $\mathrm{H} 3$ acetylation at $\mathrm{K} 27$ (H3K27ac) coincide with gene activation during embryonic development in sponges, cnidarians, planarians and vertebrates, while H3K9me3 and H3K27me3 represent repressive marks (Karlic et al. 2010; Schwaiger et al. 2014; Cunliffe 2016; Gaiti et al. 2017; Dattani et al. 2018). Accordingly, epigenetics represents one of the most active domains in biology, especially in the context of biological phenomena such as cell differentiation and development. However, epigenetics is often restricted to vertebrates and a few non-vertebrate organisms (e.g. cnidarians and poriferans), while no data have been acquired for other lineages such as annelids, thus calling for comparative studies. In Platynereis, gene coding for orthologous proteins of all main actors of 5mC DNA methylation/demethylation machinery were found (Planques et al. 2021). In addition, computational analyses (CpG observed/expected) and assays with methylation-sensitive restriction enzymes revealed a high level of DNA methylation during embryonic and larval development. Interestingly, treatment with a hypomethylating agent (Decitabine/5-aza-2'deoxycytidine) during larval development impairs parapodia, chaetae and pygidium formation and eventually leads to the death of juvenile worms, suggesting a fundamental role of DNA methylation during larval development. Similarly, Decitabine greatly delays worm regeneration and sometimes leads to abnormal posterior elongation (i.e. no or reduced number of new segments, abnormal parapodia and cirri) after drug removal. This suggests that the regenerated growth zone is affected by Decitabine-mediated hypomethylation, leading to persistent defects of its function thereafter. Now, additional data are required to assess the precise methylation patterns in Platynereis (e.g. genome-wide bisulfite sequencing) and the link between modulations in methylation patterns and changes in gene expression. Furthermore, extending 
research to other epigenetic mechanisms such as the role of post-translational Histone marks and non-coding RNA would bring additional clues to questions on the tight mechanisms controlling cell fate trajectories during dynamic processes, especially in non-vertebrate animals and during regeneration, for which studies remain highly scarce.

\section{ACKNOWLEDGMENTS}

Work in our team is supported by funding from the Labex "Who Am I" laboratory of excellence (No. ANR-11LABX-0071) funded by the French government through its "Investments for the Future" program operated by the Agence Nationale de la Recherche under grant No. ANR11-IDEX-0005-01, the Centre National de la Recherche Scientifique, the INSB department (grant "Diversity of Biological Mechanisms"), the Agence Nationale de la Recherche (grant TELOBLAST no. ANR-16-CE91-0007 and grant STEM no. ANR-19-CE27-0027-02), the "Association pour la Recherche sur le Cancer" (grant PJA 20191209482) and the "Ligue Nationale Contre le Cancer" (grant RS20/75-20). QS is a fellow of the labex "Who Am I" and the "Paris Region Fellowship Programme" 2021. We thank Dr. Nicolas Dray and Loïc Bideau for providing pictures. We are grateful to Haley Flom for critical reading of the manuscript. The authors warmly thank all current and past members of the 'Stem cells, Development and Evolution' team at the Institut Jacques Monod, Paris, France, especially Prof. Michel Vervoort for his valuable comments on this chapter.

\section{BIBLIOGRAPHY}

Achim, K., Eling, N., Vergara, H. M., Bertucci, P. Y., Musser, J., Vopalensky, P., Brunet, T., Collier, P., Benes, V., Marioni, J. C., and Arendt, D. 2018. Whole-body single-cell sequencing reveals transcriptional domains in the annelid larval body. Mol Biol Evol 35 (5):1047-1062.

Achim, K., Pettit, J. B., Saraiva, L. R., Gavriouchkina, D., Larsson, T., Arendt, D., and Marioni, J. C. 2015. High-throughput spatial mapping of single-cell RNA-seq data to tissue of origin. Nature Biotechnology 33 (5):503-U215.

Ackermann, C., Dorresteijn, A., and Fischer, A. 2005. Clonal domains in postlarval Platynereis dumerilii (Annelida: Polychaeta). J Morphol 266 (3):258-280.

Andrade, S. C., Novo, M., Kawauchi, G. Y., Worsaae, K., Pleijel, F., Giribet, G., and Rouse, G. W. 2015. Articulating "archiannelids": Phylogenomics and annelid relationships, with emphasis on meiofaunal taxa. Mol Biol Evol 32 (11):2860-2875.

Andreatta, G., Broyart, C., Borghgraef, C., Vadiwala, K., Kozin, V., Polo, A., Bileck, A., Beets, I., Schoofs, L., Gerner, C., and Raible, F. 2020. Corazonin signaling integrates energy homeostasis and lunar phase to regulate aspects of growth and sexual maturation in Platynereis. Proc Natl Acad Sci U S A 117 (2):1097-1106.

Andreatta, G., and Tessmar-Raible, K. 2020. The still dark side of the moon: Molecular mechanisms of lunar-controlled rhythms and clocks. J Mol Biol 432 (12):3525-3546.

Arboleda, E., Zurl, M., Waldherr, M., and Tessmar-Raible, K. 2019. Differential impacts of the head on Platynereis dumerilii peripheral circadian rhythms. Front Physiol 10:900.
Arendt, D. 2018. Animal evolution: Convergent nerve cords? Curr Biol 28 (5):R225-R227.

Arendt, D., Bertucci, P. Y., Achim, K., and Musser, J. M. 2019. Evolution of neuronal types and families. Curr Opin Neurobiol 56:144-152.

Arendt, D., Musser, J. M., Baker, C. V. H., Bergman, A., Cepko, C., Erwin, D. H., Pavlicev, M., Schlosser, G., Widder, S., Laubichler, M. D., and Wagner, G. P. 2016. The origin and evolution of cell types. Nat Rev Genet 17 (12):744-757.

Arendt, D., Technau, U., and Wittbrodt, J. 2001. Evolution of the bilaterian larval foregut. Nature 409 (6816):81-85.

Arendt, D., Tessmar, K., de Campos-Baptista, M. I., Dorresteijn, A., and Wittbrodt, J. 2002. Development of pigment-cup eyes in the polychaete Platynereis dumerilii and evolutionary conservation of larval eyes in Bilateria. Development 129 (5):1143-1154.

Arendt, D., Tosches, M. A., and Marlow, H. 2016. From nerve net to nerve ring, nerve cord and brain-evolution of the nervous system. Nat Rev Neurosci 17 (1):61-72.

Asadulina, A., Panzera, A., Veraszto, C., Liebig, C., and Jekely, G. 2012. Whole-body gene expression pattern registration in Platynereis larvae. Evodevo 3 (1):27.

Audouin, J. V., and Milne Edwards, H. 1833. Classification des annélides, et description de celles qui habitent les côtes de la France. In Annales des Sciences Naturelles, 195-269.

Audouin, J. V., and Milne Edwards, H. 1834. Recherches pour servir à l'histoire naturelle du littoral de la France Vol. 2, Recueil de mémoires sur l'anatomie, la physiologie, la classification et les mœurs des animaux de nos côtes. Paris.

Ayers, T., Tsukamoto, H., Guhmann, M., Veedin Rajan, V. B., and Tessmar-Raible, K. 2018. A Go-type opsin mediates the shadow reflex in the annelid Platynereis dumerilii. BMC Biol $16(1): 41$.

Backfisch, B., Kozin, V. V., Kirchmaier, S., Tessmar-Raible, K., and Raible, F. 2014. Tools for gene-regulatory analyses in the marine annelid Platynereis dumerilii. PLoS One 9 (4):e93076.

Backfisch, B., Veedin Rajan, V. B., Fischer, R. M., Lohs, C., Arboleda, E., Tessmar-Raible, K., and Raible, F. 2013. Stable transgenesis in the marine annelid Platynereis dumerilii sheds new light on photoreceptor evolution. Proc Natl Acad Sci U S A 110 (1):193-198.

Bannister, S., Antonova, O., Polo, A., Lohs, C., Hallay, N., Valinciute, A., Raible, F., and Tessmar-Raible, K. 2014. TALENs mediate efficient and heritable mutation of endogenous genes in the marine annelid Platynereis dumerilii. Genetics 197 (1):77-89.

Bely, A. E. 2010. Evolutionary loss of animal regeneration: Pattern and process. Integr Comp Biol 50 (4):515-527.

Bentley, M. G., Olive, P. J. W., and Last, K. 1999. Sexual satellites, moonlight and the nuptial dances of worms: The influence of the moon on the reproduction of marine animals. Earth, Moon, and Planets 85/86 (0):67-84.

Bezares-Calderon, L. A., Berger, J., Jasek, S., Veraszto, C., Mendes, S., Guhmann, M., Almeda, R., Shahidi, R., and Jekely, G. 2018. Neural circuitry of a polycystin-mediated hydrodynamic startle response for predator avoidance. Elife 7.

Bezares-Calderon, L. A., Berger, J., and Jekely, G. 2020. Diversity of cilia-based mechanosensory systems and their functions in marine animal behaviour. Philos Trans R Soc Lond B Biol Sci 375 (1792):20190376.

Bhambri, A., Dhaunta, N., Patel, S. S., Hardikar, M., Bhatt, A., Srikakulam, N., Shridhar, S., Vellarikkal, S., Pandey, R., Jayarajan, R., Verma, A., Kumar, V., Gautam, P., Khanna, Y., Khan, J. A., Fromm, B., Peterson, K. J., Scaria, V., Sivasubbu, 
S., and Pillai, B. 2018. Large scale changes in the transcriptome of Eisenia fetida during regeneration. PLoS One 13 (9):e0204234.

Bideau, L., Kerner, P., Hui, J., Vervoort, M., and Gazave, E. 2021. Animal regeneration in the era of transcriptomics. Cell Mol Life Sci 78:3941-3956.

Boilly, B. 1969a. Sur l'origine des cellules régénératrices chez les annélides polychètes. Archives de Zoologie expérimentale et générale 110 (1):127-143.

Boilly, B. 1969b. Experimental study of the localization, by relation to the amputation plan, of the source of mesodermal regeneration cells in an annelid polychaete (Syllis amica Quatrefages). J Embryol Exp Morphol 21 (1):193-206.

Boilly, B. 1969c. Origine des cellules régénératrices chez Nereis diversicolor O. F. Müller (Annélide Polychète). Wilhelm Roux'Archiv für Entwicklungsmechanik der Organismen 162 (3):286-305

Boilly-Marer, Y. 1973. Etude expérimentale du comportement nuptial de Platynereis dumerilii (Annélide Polychète): chémoreception, émission des produits génitaux. Marine Biology 24:167-179.

Brunet, T., Fischer, A. H., Steinmetz, P. R., Lauri, A., Bertucci, P., and Arendt, D. 2016. The evolutionary origin of bilaterian smooth and striated myocytes. Elife 5.

Brunet, T., Lauri, A., and Arendt, D. 2015. Did the notochord evolve from an ancient axial muscle? The axochord hypothesis. Bioessays 37 (8):836-850.

Brusca, R. C., and Brusca, G. J., eds. 2003. Invertebrates, second edition. Sunderland: Sinauer Associates, Inc.

Cao, J., Spielmann, M., Qiu, X., Huang, X., Ibrahim, D. M., Hill, A. J., Zhang, F., Mundlos, S., Christiansen, L., Steemers, F. J., Trapnell, C., and Shendure, J. 2019. The single-cell transcriptional landscape of mammalian organogenesis. Nature 566 (7745):496-502.

Caspers, H. 1971. C. Hauenschild und A. Fischer: Platynereis dumerilii. Mikroskopische Anatomie, Fortpflanzung, Entwicklung.-Großes Zoologisches Praktikum Heft 10b. Mit 37 Abb., Stuttgart: Gustav Fischer Verlag 1969. 55 S. DM 26,- - Internationale Revue der gesamten Hydrobiologie und Hydrographie 56 (2):326-326.

Caspers, H. 1984. Spawning periodicity and habitat of the palolo worm eunice-viridis (Polychaeta, eunicidae) in the Samoan Islands. Marine Biology 79 (3):229-236.

Chartier, T. F., Deschamps, J., Durichen, W., Jekely, G., and Arendt, D. 2018. Whole-head recording of chemosensory activity in the marine annelid Platynereis dumerilii. Open Biol 8 (10).

Chen, H., Parry, L. A., Vinther, J., Zhai, D., Hou, X., and Ma, X. 2020. A Cambrian crown annelid reconciles phylogenomics and the fossil record. Nature 583 (7815):249-252.

Choi, H. M. T., Schwarzkopf, M., Fornace, M. E., Acharya, A., Artavanis, G., Stegmaier, J., Cunha, A., and Pierce, N. A. 2018. Third-generation in situ hybridization chain reaction: Multiplexed, quantitative, sensitive, versatile, robust. Development 145 (12).

Chou, H. C., Acevedo-Luna, N., Kuhlman, J. A., and Schneider, S. Q. 2018. PdumBase: A transcriptome database and research tool for Platynereis dumerilii and early development of other metazoans. BMC Genomics 19 (1):618.

Chou, H. C., Pruitt, M. M., Bastin, B. R., and Schneider, S. Q. 2016. A transcriptional blueprint for a spiral-cleaving embryo. BMC Genomics 17:552.

Conzelmann, M., Offenburger, S. L., Asadulina, A., Keller, T., Munch, T. A., and Jekely, G. 2011. Neuropeptides regulate swimming depth of Platynereis larvae. Proc Natl Acad Sci U $S$ A 108 (46):E1174-E1183.
Conzelmann, M., Williams, E. A., Tunaru, S., Randel, N., Shahidi, R., Asadulina, A., Berger, J., Offermanns, S., and Jekely, G. 2013. Conserved MIP receptor-ligand pair regulates Platynereis larval settlement. Proc Natl Acad Sci U S A 110 (20):8224-8229.

Cunliffe, V. T. 2016. Histone modifications in zebrafish development. Methods Cell Biol 135:361-385.

Dai, H., and Wang, Z. 2014. Histone modification patterns and their responses to environment. Current Environmental Health Reports 1 (1):11-21.

Dattani, A., Kao, D., Mihaylova, Y., Abnave, P., Hughes, S., Lai, A., Sahu, S., and Aboobaker, A. A. 2018. Epigenetic analyses of planarian stem cells demonstrate conservation of bivalent histone modifications in animal stem cells. Genome Res 28 (10):1543-1554.

de Jong, D. M., and Seaver, E. C. 2018. Investigation into the cellular origins of posterior regeneration in the annelid Capitella teleta. Regeneration (Oxf) 5 (1):61-77.

de Mendoza, A., Hatleberg, W. L., Pang, K., Leininger, S., Bogdanovic, O., Pflueger, J., Buckberry, S., Technau, U., Hejnol, A., Adamska, M., Degnan, B. M., Degnan, S. M., and Lister, R. 2019. Convergent evolution of a vertebratelike methylome in a marine sponge. Nat Ecol Evol 3 (10):1464-1473.

Demilly, A., Steinmetz, P., Gazave, E., Marchand, L., and Vervoort, M. 2013. Involvement of the $\mathrm{Wnt} /$ beta-catenin pathway in neurectoderm architecture in Platynereis dumerilii. Nat Commun 4:1915.

Denes, A. S., Jekely, G., Steinmetz, P. R., Raible, F., Snyman, H., Prud'homme, B., Ferrier, D. E., Balavoine, G., and Arendt, D. 2007. Molecular architecture of annelid nerve cord supports common origin of nervous system centralization in bilateria. Cell 129 (2):277-288.

de Quatrefarges, A. 1865. Note sur la classification des Annélides. Comptes rendus hebdomadaires des séances de l'Académie des sciences 60:586-600.

Dorresteijn, A. W. 1990. Quantitative analysis of cellular differentiation during early embryogenesis of Platynereis dumerilii. Rouxs Arch Dev Biol 199 (1):14-30.

Dorresteijn, A. W., Bornewasser, H., and Fischer, A. 1987. A correlative study of experimentally changed first cleavage and Janus development in the trunk of Platynereis dumerilii (Annelida, Polychaeta). Rouxs Arch Dev Biol 196 (1):51-58.

Dorresteijn, A. W., O'Grady, B., Fischer, A., Porchet-Hennere, E., and Boilly-Marer, Y. 1993. Molecular specification of cell lines in the embryo of Platynereis (Annelida). Rouxs Arch Dev Biol 202 (5):260-269.

Dorsett, D. A., and Hyde, R. 1969. The fine structure of the compound sense organs on the cirri of Nereis diversicolor. $Z$ Zellforsch Mikrosk Anat 97 (4):512-527.

Dray, N., Tessmar-Raible, K., Le Gouar, M., Vibert, L., Christodoulou, F., Schipany, K., Guillou, A., Zantke, J., Snyman, H., Behague, J., Vervoort, M., Arendt, D., and Balavoine, G. 2010. Hedgehog signaling regulates segment formation in the annelid Platynereis. Science 329 (5989):339-342.

Fauvel, P. 1923. Polychètes errantes. Faune de France 5:1-488.

Fauvel, P. 1927. Polychètes Sédentaires. Addenda aux Errantes, Archiannélides, Myzostomaires. Faune de France 16:1-494.

Ferrier, D. E. 2012. Evolutionary crossroads in developmental biology: Annelids. Development 139 (15):2643-2653.

Fischer, A. 1974. Stages and stage distribution in early oogenesis in the Annelid, Platynereis dumerilii. Cell Tissue Res 156 (1):35-45.

Fischer, A. 1999. Reproductive and developmental phenomena in annelids: A source of exemplary research problems. In 
Reproductive Strategies and Developmental Patterns in Annelids, edited by W. Westheide and A. W. C. Dorresteijn, 1-20. Dordrecht: Springer Netherlands.

Fischer, A., and Dorresteijn, A. 2004. The polychaete Platynereis dumerilii (Annelida): A laboratory animal with spiralian cleavage, lifelong segment proliferation and a mixed benthic/ pelagic life cycle. Bioessays 26 (3):314-325.

Fischer, A. H., Henrich, T., and Arendt, D. 2010. The normal development of Platynereis dumerilii (Nereididae, Annelida). Front Zool 7:31.

Fischer, A. H. L., and Arendt, D. 2013. Mesoteloblast-like mesodermal stem cells in the polychaete annelid Platynereis dumerilii (Nereididae). Journal of Experimental Zoology Part B-Molecular and Developmental Evolution 320b (2):94-104.

Gaiti, F., Jindrich, K., Fernandez-Valverde, S. L., Roper, K. E., Degnan, B. M., and Tanurdzic, M. 2017. Landscape of histone modifications in a sponge reveals the origin of animal cis-regulatory complexity. Elife 6.

Gambi, M. C., Zupo, V., Buia, M. C., and Mazzella, L. 2000. Feeding Ecology of Platynereis dumerilii (Audouin \& Milne-Edwards) in the Seagrass Posidonia Oceanica System: The Role of the Epiphytic Flora (Polychaeta, Nereididae). Ophelia 12 (53):189-202.

Gazave, E., Behague, J., Laplane, L., Guillou, A., Preau, L., Demilly, A., Balavoine, G., and Vervoort, M. 2013. Posterior elongation in the annelid Platynereis dumerilii involves stem cells molecularly related to primordial germ cells. Dev Biol 382 (1):246-267.

Gazave, E., Lemaitre, Q. I. B., and Balavoine, G. 2017. The Notch pathway in the annelid Platynereis: Insights into chaetogenesis and neurogenesis processes. Open Biology 7 (2).

Gazave, E., and Rottinger, E. 2021. 7th Euro Evo Devo meeting: Report on the "evolution of regeneration in Metazoa" symposium. J Exp Zool (Mol Dev Evol) 336:89-93.

Gerber, T., Murawala, P., Knapp, D., Masselink, W., Schuez, M., Hermann, S., Gac-Santel, M., Nowoshilow, S., Kageyama, J., Khattak, S., Currie, J. D., Camp, J. G., Tanaka, E. M., and Treutlein, B. 2018. Single-cell analysis uncovers convergence of cell identities during axolotl limb regeneration. Science 362 (6413).

Giangrande, A., Fraschetti, S., and Terlizzi, A. 2002. Local recruitment differences in Platynereis dumerilii (Polychaeta, Nereididae) and their consequences for population structure. Italian Journal of Zoology 69 (2):133-139.

Greenberg, M. V. C., and Bourc'his, D. 2019. The diverse roles of DNA methylation in mammalian development and disease. Nat Rev Mol Cell Biol 20 (10):590-607.

Grillo, M., Konstantinides, N., and Averof, M. 2016. Old questions, new models: Unraveling complex organ regeneration with new experimental approaches. Curr Opin Genet Dev 40:23-31.

Grimmel, J., Dorresteijn, A. W., and Frobius, A. C. 2016. Formation of body appendages during caudal regeneration in Platynereis dumerilii: Adaptation of conserved molecular toolsets. Evodevo 7:10.

Guhmann, M., Jia, H., Randel, N., Veraszto, C., Bezares-Calderon, L. A., Michiels, N. K., Yokoyama, S., and Jekely, G. 2015. Spectral tuning of phototaxis by a go-opsin in the rhabdomeric eyes of Platynereis. Curr Biol 25 (17):2265-2271.

Hasse, C., Rebscher, N., Reiher, W., Sobjinski, K., Moerschel, E., Beck, L., Tessmar-Raible, K., Arendt, D., and Hassel, M. 2010. Three consecutive generations of nephridia occur during development of Platynereis dumerilii (Annelida, Polychaeta). Dev Dyn 239 (7):1967-1976.
Hauenschild, C. 1955. Photoperiodizität als ursache des von der mondphase abhangigen metamorphose-rhythmus bei dem polychaeten Platynereis dumerilii. Z. Naturforsch. B. 10:658-662.

Hauenschild, C. 1956. Hormonale Hemmung der Geschlechtsreife und Metamorphose bei dem Polychaeten Platynereis dumerilii. Zeitschrift für Naturforschung B 11 (3):125-132.

Hauenschild, C. 1960. Abhängigkeit der Regenerationsleistung von der inneren Sekretion im Prostomium bei Platynereis dumerilii. Zeitschrift für Naturforschung B 15 (1):52-55.

Heuer, C. M., Muller, C. H., Todt, C., and Loesel, R. 2010. Comparative neuroanatomy suggests repeated reduction of neuroarchitectural complexity in Annelida. Front Zool 7:13.

Hofmann, D. K. 1976. Regeneration and endocrinology in the polychaete Platynereis dumerilii: An experimental and structural study. Wilehm Roux Arch Dev Biol 180 (1):47-71.

Jacobs, R. P. W. M., and Pierson, E. S. 1979. Zostera marina spathes as a habitat for Platynereis dumerilii (Audouin and Milne-Edwards, 1834). Aquatic Botany 6:403-406.

Jekely, G., Melzer, S., Beets, I., Kadow, I. C. G., Koene, J., Haddad, S., and Holden-Dye, L. 2018. The long and the short of it: A perspective on peptidergic regulation of circuits and behaviour. J Exp Biol 221 (Pt 3).

Jha, A. N., Hutchinson, T. H., Mackay, J. M., Elliott, B. M., Pascoe, P. L., and Dixon, D. R. 1995. The chromosomes of Platynereis dumerilii (Polychaeta, Nereidae). Journal of the Marine Biological Association of the United Kingdom 75 (3):551-562.

Juliano, C. E., Swartz, S. Z., and Wessel, G. M. 2010. A conserved germline multipotency program. Development 137 (24):4113-4126.

Just, E. E. 1929. Breeding habits of Nereis dumerilii at Naples. Biol Bull 57 (5):307-310.

Kara, J., Santos, C. S. G., Macdonald, Angus, H. H., and Simon, C. A. 2020. Resolving the taxonomic identities and genetic structure of two cryptic Platynereis Kinberg species from South Africa. Invertebrate Systematics 34 (6):618-636, 619.

Karlic, R., Chung, H. R., Lasserre, J., Vlahovicek, K., and Vingron, M. 2010. Histone modification levels are predictive for gene expression. Proc Natl Acad Sci U S A 107 (7):2926-2931.

Kenny, N. J., Namigai, E. K., Marletaz, F., Hui, J. H., and Shimeld, S. M. 2015. Draft genome assemblies and predicted microRNA complements of the intertidal lophotrochozoans Patella vulgata (Mollusca, Patellogastropoda) and Spirobranchus (Pomatoceros) lamarcki (Annelida, Serpulida). Mar Genomics 24 (Pt 2):139-146.

Knowlton, N. 1993. Sibling species in the sea. Annual Review of Ecology and Systematics 24 (1):189-216.

Kostyuchenko, R. P., and Kozin, V. V. 2020. Morphallaxis versus epimorphosis? Cellular and molecular aspects of regeneration and asexual reproduction in annelids. Biology Bulletin 47 (3):237-246.

Kuehn, E., Stockinger, A. W., Girard, J., Raible, F., and Ozpolat, B. D. 2019. A scalable culturing system for the marine annelid Platynereis dumerilii. PLoS One 14 (12):e0226156.

Lamarck, J. B. 1818. Histoire naturelle des animaux sans vertèbres. Vol. 5. Paris: Deterville \& Verdiere.

Laumer, C. E., Fernandez, R., Lemer, S., Combosch, D., Kocot, K. M., Riesgo, A., Andrade, S. C. S., Sterrer, W., Sorensen, M. V., and Giribet, G. 2019. Revisiting metazoan phylogeny with genomic sampling of all phyla. Proc Biol Sci 286 (1906):20190831.

Lauri, A., Brunet, T., Handberg-Thorsager, M., Fischer, A. H., Simakov, O., Steinmetz, P. R., Tomer, R., Keller, P. J., and Arendt, D. 2014. Development of the annelid 
axochord: Insights into notochord evolution. Science 345 (6202):1365-1368.

Li, Y., Tassia, M. G., Waits, D. S., Bogantes, V. E., David, K. T., and Halanych, K. M. 2019. Genomic adaptations to chemosymbiosis in the deep-sea seep-dwelling tubeworm Lamellibrachia luymesi. BMC Biol 17 (1):91.

Marinkovic, M., Berger, J., and Jekely, G. 2020. Neuronal coordination of motile cilia in locomotion and feeding. Philos Trans R Soc Lond B Biol Sci 375 (1792):20190165.

Marlow, H., Tosches, M. A., Tomer, R., Steinmetz, P. R., Lauri, A., Larsson, T., and Arendt, D. 2014. Larval body patterning and apical organs are conserved in animal evolution. BMC Biol 12:7.

Martin-Duran, J. M., Vellutini, B. C., Marletaz, F., Cetrangolo, V., Cvetesic, N., Thiel, D., Henriet, S., Grau-Bové, X., Carillo-Baltodano, A. M., Gu, W., Kerbl, A., Marquez, Y., Bekkouche, N., Chourrout, D., Gomez-Skarmeta, J. L., Irimia, M., Lenhard, B., Worsaae, K., and Hejnol, A. 2021. Conservative route to genome compaction in a miniature annelid. Nature Ecology \& Evolution 5:231-242.

M'Intosh, W. C., Ford, G. H., McIntosh, R., and Walker, A. H. 1910. A Monograph of the British Marine Annelids. Vol. 2:pt.2 (1910). London: The Ray Society.

Moquin-Tandon, G. 1869. Note sur une nouvelle annelide chetopode hermaphrodite (Nereis massiliensis). Annales des Sciences Naturelles 9:97-106.

Morgan, T. H. 1901. Regeneration. New York: Macmillan.

Myohara, M. 2012. What role do annelid neoblasts play? A comparison of the regeneration patterns in a neoblast-bearing and a neoblast-lacking enchytraeid oligochaete. PLoS One 7 (5):e37319.

Nicoglou, A., and Merlin, F. 2017. Epigenetics: A way to bridge the gap between biological fields. Stud Hist Philos Biol Biomed Sci 66:73-82.

Nielsen, C., Brunet, T., and Arendt, D. 2018. Evolution of the bilaterian mouth and anus. Nat Ecol Evol 2 (9):1358-1376.

Nikanorova, D. D., Kupriashova, E. E., and Kostyuchenko, R. P. 2020. Regeneration in annelids: Cell sources, tissue remodeling, and differential gene expression. Russian Journal of Developmental Biology 51 (3):148-161.

Ozpolat, B. D., and Bely, A. E. 2016. Developmental and molecular biology of annelid regeneration: A comparative review of recent studies. Curr Opin Genet Dev 40:144-153.

Ozpolat, B. D., Handberg-Thorsager, M., Vervoort, M., and Balavoine, G. 2017. Cell lineage and cell cycling analyses of the $4 \mathrm{~d}$ micromere using live imaging in the marine annelid Platynereis dumerilii. Elife 6.

Parry, L. A., Edgecombe, G. D., Eibye-Jacobsen, D., and Vinther, J. 2016. The impact of fossil data on annelid phylogeny inferred from discrete morphological characters. Proc Biol Sci 283 (1837).

Perez-Garijo, A., and Steller, H. 2015. Spreading the word: Non-autonomous effects of apoptosis during development, regeneration and disease. Development 142 (19): 3253-3262.

Pijuan-Sala, B., Griffiths, J. A., Guibentif, C., Hiscock, T. W., Jawaid, W., Calero-Nieto, F. J., Mulas, C., Ibarra-Soria, X., Tyser, R. C. V., Ho, D. L. L., Reik, W., Srinivas, S., Simons, B. D., Nichols, J., Marioni, J. C., and Gottgens, B. 2019. A single-cell molecular map of mouse gastrulation and early organogenesis. Nature 566 (7745):490-495.

Piper, R. 2015. Animal Earth: The Amazing Diversity of Living Creatures. London: Thames \& Hudson, Ltd.

Planques, A., Kerner, P., Ferry, L., Grunau, C., Gazave, E., and Vervoort, M. 2021. DNA methylation atlas and machinery in the developing and regenerating annelid Platynereis dumerilii. BMC Bio. 19: 148.

Planques, A., Malem, J., Parapar, J., Vervoort, M., and Gazave, E. 2019. Morphological, cellular and molecular characterization of posterior regeneration in the marine annelid Platynereis dumerilii. Dev Biol 445 (2):189-210.

Poss, K. D. 2010. Advances in understanding tissue regenerative capacity and mechanisms in animals. Nat Rev Genet 11 (10):710-722.

Prud'homme, B., de Rosa, R., Arendt, D., Julien, J. F., Pajaziti, R., Dorresteijn, A. W., Adoutte, A., Wittbrodt, J., and Balavoine, G. 2003. Arthropod-like expression patterns of engrailed and wingless in the annelid Platynereis dumerilii suggest a role in segment formation. Curr Biol 13 (21):1876-1881.

Purschke, G. 2005. Sense organs in polychaetes (Annelida). Hydrobiologia 535:53-78.

Raible, F., and Falciatore, A. 2014. It's about time: Rhythms as a new dimension of molecular marine research. Mar Genomics 14:1-2.

Raible, F., Takekata, H., and Tessmar-Raible, K. 2017. An overview of monthly rhythms and clocks. Front Neurol 8:189.

Raible, F., Tessmar-Raible, K., Osoegawa, K., Wincker, P., Jubin, C., Balavoine, G., Ferrier, D., Benes, V., de Jong, P., Weissenbach, J., Bork, P., and Arendt, D. 2005. Vertebratetype intron-rich genes in the marine annelid Platynereis dumerilii. Science 310 (5752):1325-1326.

Randel, N., Asadulina, A., Bezares-Calderon, L. A., Veraszto, C., Williams, E. A., Conzelmann, M., Shahidi, R., and Jekely, G. 2014. Neuronal connectome of a sensory-motor circuit for visual navigation. Elife 3.

Randel, N., Shahidi, R., Veraszto, C., Bezares-Calderon, L. A., Schmidt, S., and Jekely, G. 2015. Inter-individual stereotypy of the Platynereis larval visual connectome. Elife 4:e08069.

Read, G., and Fauchald, K. 2018. World Polychaeta database. Platynereis dumerilii (Audouin \& Milne Edwards, 1833).

Rebscher, N., Lidke, A. K., and Ackermann, C. F. 2012. Hidden in the crowd: Primordial germ cells and somatic stem cells in the mesodermal posterior growth zone of the polychaete Platynereis dumerilii are two distinct cell populations. Evodevo 3:9.

Ribeiro, R. P., Ponz-Segrelles, G., Bleidorn, C., and Aguado, M. T. 2019. Comparative transcriptomics in Syllidae (Annelida) indicates that posterior regeneration and regular growth are comparable, while anterior regeneration is a distinct process. BMC Genomics 20 (1).

Ricci, L., and Srivastava, M. 2018. Wound-induced cell proliferation during animal regeneration. Wiley Interdiscip Rev Dev Biol: e321.

Rouse, G. W., and Fauchald, K. 1997. Cladistics and polychaetes. Zoologica Scripta 26 (2):139-204.

Rouse, G. W., and Pleijel, F. 2001. Polychaetes. New York: Oxford University Press

Saudemont, A., Dray, N., Hudry, B., Le Gouar, M., Vervoort, M., and Balavoine, G. 2008. Complementary striped expression patterns of NK homeobox genes during segment formation in the annelid Platynereis. Dev Biol 317 (2):430-443.

Schenk, S., Bannister, S. C., Sedlazeck, F. J., Anrather, D., Minh, B. Q., Bileck, A., Hartl, M., von Haeseler, A., Gerner, C., Raible, F., and Tessmar-Raible, K. 2019. Combined transcriptome and proteome profiling reveals specific molecular brain signatures for sex, maturation and circalunar clock phase. Elife 8.

Schenk, S., Krauditsch, C., Fruhauf, P., Gerner, C., and Raible, F. 2016. Discovery of methylfarnesoate as the annelid brain hormone reveals an ancient role of sesquiterpenoids in reproduction. Elife 5. 
Schmarda, L. K. 1861. Neue Wirbellose Thiere: Beobachted und Gesammelt auf einer Reise um die Erdr 1853 bis 1857. In In Turbellarien, Rotatorien und Anneliden, edited by Zweite Hälfte Erster Band. Leipzig: Verlag von Wilhelm Engelmann.

Schmidtberg, H., and Dorresteijn, A. W. C. 2010. Ultrastructure of the nuchal organs in the polychaete Platynereis dumerilii (Annelida, Nereididae). Invertebrate Biology 129 (3):252-265.

Schneider, S. Q., and Bowerman, B. 2007. Beta-catenin asymmetries after all animal/vegetal-oriented cell divisions in Platynereis dumerilii embryos mediate binary cell-fate specification. Dev Cell 13 (1):73-86.

Scholtz, G. 2002. The Articulata hypothesis: Or what is a segment? Organisms Diversity \& Evolution 2 (3):197-215.

Schroeder, P. C., Aguado, M. T., Malpartida, A., and Glasby, C. J. 2017. New observations on reproduction in the branching polychaetes Ramisyllis multicaudata and Syllis ramosa (Annelida: Syllidae: Syllinae). Journal of the Marine Biological Association of the United Kingdom 97 (5):1167-1175.

Schulz, G., Ulbrich, K. P., Hauenschild, C., and Pfannenstiel, H. D. 1989. The atokous-epitokous border is determined before the onset of heteronereid development in Platynereis dumerilii (Annelida, Polychaeta). Rouxs Arch Dev Biol 198 (1):29-33.

Schwaiger, M., Schonauer, A., Rendeiro, A. F., Pribitzer, C., Schauer, A., Gilles, A. F., Schinko, J. B., Renfer, E., Fredman, D., and Technau, U. 2014. Evolutionary conservation of the eumetazoan gene regulatory landscape. Genome Res 24 (4):639-650.

Shao, Y., Wang, X. B., Zhang, J. J., Li, M. L., Wu, S. S., Ma, X. Y., Wang, X., Zhao, H. F., Li, Y., Zhu, H. H., Irwin, D. M., Wang, D. P., Zhang, G. J., Ruan, J., and Wu, D. D. 2020. Genome and single-cell RNA-sequencing of the earthworm Eisenia andrei identifies cellular mechanisms underlying regeneration. Nat Commun 11 (1):2656.

Simakov, O., Marletaz, F., Cho, S. J., Edsinger-Gonzales, E., Havlak, P., Hellsten, U., Kuo, D. H., Larsson, T., Lv, J., Arendt, D., Savage, R., Osoegawa, K., de Jong, P., Grimwood, J., Chapman, J. A., Shapiro, H., Aerts, A., Otillar, R. P., Terry, A. Y., Boore, J. L., Grigoriev, I. V., Lindberg, D. R., Seaver, E. C., Weisblat, D. A., Putnam, N. H., and Rokhsar, D. S. 2013. Insights into bilaterian evolution from three spiralian genomes. Nature 493 (7433):526-531.

Starunov, V. V., Dray, N., Belikova, E. V., Kerner, P., Vervoort, M., and Balavoine, G. 2015. A metameric origin for the annelid pygidium? BMC Evol Biol 15:25.

Starunov, V. V., Voronezhskaya, E. E., and Nezlin, L. P. 2017. Development of the nervous system in Platynereis dumerilii (Nereididae, Annelida). Front Zool 14:27.

Steinmetz, P. R., Zelada-Gonzales, F., Burgtorf, C., Wittbrodt, J., and Arendt, D. 2007. Polychaete trunk neuroectoderm converges and extends by mediolateral cell intercalation. Proc Natl Acad Sci U S A 104 (8):2727-2732.

Struck, T. H. 2011. Direction of evolution within Annelida and the definition of Pleistoannelida. Journal of Zoological Systematics and Evolutionary Research 49 (4):340-345.

Struck, T. H., Paul, C., Hill, N., Hartmann, S., Hosel, C., Kube, M., Lieb, B., Meyer, A., Tiedemann, R., Purschke, G., and Bleidorn, C. 2011. Phylogenomic analyses unravel annelid evolution. Nature 471 (7336):95-98.

Sugio, M., Yoshida-Noro, C., Ozawa, K., and Tochinai, S. 2012. Stem cells in asexual reproduction of Enchytraeus japonensis (Oligochaeta, Annelid): Proliferation and migration of neoblasts. Development Growth \& Differentiation 54 (4):439-450.
Suzuki, M. M., and Bird, A. 2008. DNA methylation landscapes: Provocative insights from epigenomics. Nat Rev Genet 9 (6):465-476.

Tanaka, E. M. 2016. The molecular and cellular choreography of appendage regeneration. Cell 165 (7):1598-1608.

Tanaka, E. M., and Reddien, P. W. 2011. The cellular basis for animal regeneration. Dev Cell 21 (1):172-185.

Tessmar-Raible, K., Raible, F., and Arboleda, E. 2011. Another place, another timer: Marine species and the rhythms of life. Bioessays 33 (3):165-172.

Tessmar-Raible, K., Raible, F., Christodoulou, F., Guy, K., Rembold, M., Hausen, H., and Arendt, D. 2007. Conserved sensory-neurosecretory cell types in annelid and fish forebrain: Insights into hypothalamus evolution. Cell 129 (7):1389-1400.

Tessmar-Raible, K., Steinmetz, P. R., Snyman, H., Hassel, M., and Arendt, D. 2005. Fluorescent two-color whole mount in situ hybridization in Platynereis dumerilii (Polychaeta, Annelida), an emerging marine molecular model for evolution and development. Biotechniques 39 (4):460, 462, 464.

Tomer, R., Denes, A. S., Tessmar-Raible, K., and Arendt, D. 2010. Profiling by image registration reveals common origin of annelid mushroom bodies and vertebrate pallium. Cell 142 (5):800-809.

Valvassori, G., Massa-Gallucci, A., and Gambi, M. C. 2015. Reappraisal of Platynereis massiliensis (Moquin-Tandon) (Annelida, Nereididae), a neglected sibling species of Platynereis dumerilii (Audouin \& Milne Edwards). Biologia Marina Mediterranea 22 (1):113-116.

Veedin-Rajan, V. B., Fischer, R. M., Raible, F., and Tessmar-Raible, K. 2013. Conditional and specific cell ablation in the marine annelid Platynereis dumerilii. PLoS One 8 (9):e75811.

Veraszto, C., Ueda, N., Bezares-Calderon, L. A., Panzera, A., Williams, E. A., Shahidi, R., and Jekely, G. 2017. Ciliomotor circuitry underlying whole-body coordination of ciliary activity in the Platynereis larva. Elife 6.

Verdonschot, P. F. M. 2015. Introduction to annelida and the class polychaeta. In Thorp and Covich's Freshwater Invertebrates, edited by James H. Thorp and Christopher Rogers, 509-528. Elsevier Inc.; London: Academic Press.

Vergara, H. M., Bertucci, P. Y., Hantz, P., Tosches, M. A., Achim, K., Vopalensky, P., and Arendt, D. 2017. Whole-organism cellular gene-expression atlas reveals conserved cell types in the ventral nerve cord of Platynereis dumerilii. Proc Natl Acad Sci U S A 114 (23):5878-5885.

Vervoort, M., and Gazave, E. in press. Zoological and molecular methods to study Annelida regeneration using Platynereis dumerilii. In Methods in Molecular Biology, edited by Stephen Stricker David Carroll. Springer.

Vriz, S., Reiter, S., and Galliot, B. 2014. Cell death: A program to regenerate. Curr Top Dev Biol 108:121-151.

Vullien, A., Röttinger, E., Vervoort, M., and Gazave, E. 2021. A trio of mechanisms involved in regeneration initiation in animals. Médecine/Sciences (in French) 37 (4):349-358.

Wäge, J., Valvassori, G., Hardege, J. D., Schulze, A., and Gambi, M. C. 2017. The sibling polychaetes Platynereis dumerilii and Platynereis massiliensis in the Mediterranean Sea: Are phylogeographic patterns related to exposure to ocean acidification? Marine Biology 164 (10):164-199.

Weigert, A., and Bleidorn, C. 2016. Current status of annelid phylogeny. Organisms Diversity \& Evolution 16 (2):345-362.

Weigert, A., Helm, C., Meyer, M., Nickel, B., Arendt, D., Hausdorf, B., Santos, S. R., Halanych, K. M., Purschke, G., Bleidorn, C., and Struck, T. H. 2014. Illuminating the base of the annelid tree using transcriptomics. Mol Biol Evol 31 (6):1391-1401. 
Williams, E. A., Conzelmann, M., and Jekely, G. 2015. Myoinhibitory peptide regulates feeding in the marine annelid Platynereis. Front Zool 12 (1):1.

Williams, E. A., and Jekely, G. 2016. Towards a systems-level understanding of development in the marine annelid Platynereis dumerilii. Curr Opin Genet Dev 39:175-181.

Williams, E. A., and Jekely, G. 2019. Neuronal cell types in the annelid Platynereis dumerilii. Curr Opin Neurobiol 56:106-116.

Williams, E. A., Veraszto, C., Jasek, S., Conzelmann, M., Shahidi, R., Bauknecht, P., Mirabeau, O., and Jekely, G. 2017. Synaptic and peptidergic connectome of a neurosecretory center in the annelid brain. Elife 6 .

Williams, T. A., and Nagy, L. M. 2017. Linking gene regulation to cell behaviors in the posterior growth zone of sequentially segmenting arthropods. Arthropod Struct Dev 46 (3):380-394.

Wilson, E. B. 1892. The cell-lineage of Nereis: A contribution to the cytogeny of the annelid body. J Morphol 6 (3):361-480.

Zakrzewski, A. C. 2011. Molecular Characterization of Chaetae Formation in Annelida and Other Lophotrochozoa. Doktors der Naturwissenschaften, Fachbereich Biologie, Chemie und Pharmazie der Freien, Berlin.

Zantke, J., Bannister, S., Rajan, V. B., Raible, F., and TessmarRaible, K. 2014. Genetic and genomic tools for the marine annelid Platynereis dumerilii. Genetics 197 (1):19-31.

Zantke, J., Ishikawa-Fujiwara, T., Arboleda, E., Lohs, C., Schipany, K., Hallay, N., Straw, A. D., Todo, T., and Tessmar-Raible, K. 2013. Circadian and circalunar clock interactions in a marine annelid. Cell Rep 5 (1):99-113.

Zeeck, E., Hardege, J., and Bartels-Hardege, H. 1990. Sex pheromones and reproductive isolation in two nereid species, Nereis succinea and Platynereis dumerilii. Marine Ecology Progress Series 67:183-188.

Zemach, A., McDaniel, I. E., Silva, P., and Zilberman, D. 2010. Genome-wide evolutionary analysis of eukaryotic DNA methylation. Science 328 (5980):916-919.

Zidek, R., Machon, O., and Kozmik, Z. 2018. Wnt/beta-catenin signalling is necessary for gut differentiation in a marine annelid, Platynereis dumerilii. Evodevo 9:14. 